\title{
VERTICAL RESTRAINTS AND POWERFUL HEALTH INSURERS: EXCLUSIONARY CONDUCT MASQUERADING AS MANAGED CARE?
}

\author{
Frances H. Miller*
}

\section{INTRODUCTION}

Overt competition is a relative newcomer to the health care field-a field rarely even referred to as an industry a mere twenty-five years ago. In the early sixties most observers still considered commercial motives basically inapplicable to the delivery of medical services. ${ }^{1}$ But perceptions have changed now that more than 11 percent of the gross national product is spent on the health sector of the economy, a development made possible primarily because insurance to pay for expensive treatment and technology has become more widely available. Delivering medical services is commonly considered big business now, and the same kinds of competitive and anticompetitive behavior that have always been found in commercial markets can be clearly observed in the health industry of the 1980's. ${ }^{2}$ Moreover, health insurers have evolved into major actors in the medical morality play, shaping policy as middlemen by "managing" the costs of care through vertical restraints on provider autonomy that might have seemed inconceivable to their cost-passthrough predecessors. ${ }^{3}$

Managed care ${ }^{4}$ coverage has itself injected a vigorous dose of competition into United States health insurance markets, both with respect to employers,

\section{Copyright $\odot 1989$ by Law and Contemporary Problems}

* Professor of Law, Boston University School of Law and Professor of Public Health, Boston University School of Medicine. Joe Brodley, Barry Costilo, George Hay, Bill Page, and John Thompson made valuable contributions to an earlier draft. Graphics courtesy of Caye Sarber and Charles Normand.

1. Congress still held that view as recently as 1974. See 1974 Senate Report on the Nat'L Health Planning and Resources Dev. Act of 1974, S. Rep. No. 543-36, at 39 ("[T] the health care industry does not respond to classic marketplace forces."). By the time the 1979 amendments to that statute were enacted, however, Congress intended that "competition and consumer choice" were to be favored in making regulatory decisions in the health industry, whenever they "can constructively serve ... to advance the purposes of quality assurance, cost effectiveness and access" to health care. 42 U.S.C. \& 300k-2(a)(17) (Supp. III 1979).

2. See generally M. Noetner, Competition Among Hospitals, (1987); Havighurst, Competition in Health Services: Overviews, Issues and Answers, 34 VAND. L. Rev. 1117 (1981); FTC, Competition in the Health Care Sector: Past, Present and Future (W. Greenberg ed. 1978). On for-profit hospitals, see Light, Corporate Medicine for Profit, 255 ScI. Am. No. 6, 38 (Dec. 1986).

3. See infra text accompanying notes 39-41.

4. See infra text accompanying notes 12-16 for definition of the term. 
who subsidize three-fourths of private coverage, ${ }^{5}$ and patients, who generally exercise more limited choice among the competing plans offered through employment. Prepaid managed care plans, wherein comprehensive medical services are insured for an annual capitation fee, have begun to erode the traditional dominance of fee-for-service coverage in health insurance markets. The shift to managed care has also produced a subsidiary impact on competition in the market for health services, which has intensified, because the decision to purchase medical care has itself become more fragmented in response to cost-containment demands. ${ }^{6}$ But the vertical restraints of managed care can be manipulated to do more than merely control costs; some of them can be used strategically to exclude competitors under the guise of promoting efficient delivery of services.

This article examines how antitrust theory applies to the "management" of medical care and its effects on competition in both the health insurance and the health services markets. It focuses on the way antitrust should evaluate the impact of managed care's vertical restraints on competition among health care providers, and examines the reverberations those restraints in turn produce on insurance markets. Particular attention is given to issues raised when the manager already enjoys a large share of the health insurance market, as do the Blue Cross and Blue Shield organizations in many states, ${ }^{7}$ and then attempts to penetrate the provider market as well. Such powerful middlemen sometimes seek to protect insurance market share by using insurance industry leverage in the form of vertical restraints. These restraints facilitate middleman entry to provider markets as prepaid plan provider-competitors. ${ }^{8}$ When such entry occurs, antitrust courts should be particularly alert to the possibility of anticompetitive exclusionary behavior masquerading as procompetitive managed care. ${ }^{9}$ Courts should examine the business

5. Employer-subsidized group health insurance is the most common employee benefit offered in this country; almost $75 \%$ of U.S. workers have employer-sponsored health insurance coverage. Employee Benefit Res. Inst., Fundamental.s of Employee Benefit Programs 175 (3d ed. 1987). Employers either contract with third party insurers for employee coverage or self-insure their own plans. See id. at 175-226.

6. See text accompanying diagram 1 See also Ball Memorial Hosp. v. Mutual Hosp. Ins., 784 F.2d 1325, 1330 (7th Cir. 1986).

7. The Blues have been losing market share over the past decade in the face of incense competition from prepaid plans. Freudenheim, Economically Battered Blue Cross Struggles to Remain as Top Insurer, N.Y. Times, Apr. 2, 1989, at 1, col. 5. In some states-for example, Rhode Island-the Blues are technically separate corporate entities, usually insuring hospital services through Blue Cross and physician services through Blue Shield. In other states-for example, Connecticut-they have merged into a single firm providing insurance coverage for both kinds of services.

8. This entry is undertaken as a vertically integrated insurer/provider. Readers of this article should take care to distinguish between the concepts of vertical restraint and vertical integration, which are used throughout. Vertical restraints are restrictions, usually pertaining at least nominally to cost containment, imposed by health insurers on providers delivering managed care. Vertical integration, on the other hand, occurs when insurance and provider functions, which are generally provided at two different stages of production, are more or less assimilated within the same firm. Vertical restraints are inherent in all managed care health insurance plans, whether or not they are vertically integrated.

9. A similar analysis does not necessarily apply when powerful provider networks seek to enter the insurance market by integrating vertically because managed care's cost-containment restraints are imposed by insurers on providers, but not vice versa. Moreover, provider networks rarely have 
justification for challenged practices closely, to determine whether those practices merely constitute cover for an attempt to eliminate competitors.

The first section of this article (Parts II and III) provides background on managed care and sketches the typical organizational forms and operational methods of prototype managed care plans. The second section (Part IV) briefly outlines the major antitrust issues related to organizational structure and vertical restraints. The third section (Part V) concentrates on problems associated with vertical restraints imposed by insurers with significant market shares. ${ }^{10}$ In particular, it analyzes five federal court opinions ${ }^{11}$ that challenge managed care constraints imposed by Blue Cross/Blue Shield organizations in various states.

Analysis of these cases illuminates the shifting antitrust implications of vertical arrangements when the manager is a powerful insurer with a large fee-for-service insurance market share. The analysis demonstrates how antitrust concerns intensify when the Blues offer prepaid plans in addition to their traditional fee-for-service product and attempt to use their insurance market power to enhance their own competitive inroads on service delivery markets. Certain vertical restraints on providers common to managing care may not offend the antitrust laws when imposed by a more or less monopsonistic insurer-buyer of medical services competing only with respect to the insurance market. They can cause problems from the perspective of section 2 of the Sherman Act, however, when the insurer employs them for exclusionary ends. This is particularly true when the insurer is competing as a provider in the medical service market as well.

II

\section{BACKGROUND}

"Managed" care is used here to describe a wide variety of health care financing arrangements, ${ }^{12}$ including some that are government-sponsored ${ }^{13}$ and many that offer comprehensive prepaid health services for a yearly

the medical service market share possessed by powerful insurers. See infra text accompanying notes $100-02$.

10. "Significant market share" does not necessarily equate with an insurer's true monopoly or monopsony power for purposes of this article, but it implies a potential for dominance and therefore a lurking danger of monopolistic or monopsonistic behavior.

According to one commentator, "an insurer who has dominant market power in the sale of health insurance also will have dominant market power in the purchase of physicians' services because it must acquire services from the physicians' market to meet the needs of its insureds." Note, Preferred Provider Organizations and Provider Contracting: New Analyses Under the Sherman Acl, 37 Hastings L.J. 377, 384 (1985).

11. Kartell v. Blue Shield of Mass., 749 F.2d 922 (1st Cir. 1984), cert. denied, 471 U.S. 1029 (1985); Barry v. Blue Cross of Cal., 805 F.2d 866 (9th Cir. 1986); Ball Memorial Hosp. v. Mutual Hosp. Ins., 784 F.2d 1325 (7th Cir. 1986); Reazin v. Blue Cross \& Blue Shield of Kan., 663 F. Supp. 1360 (D. Kan. 1987); Ocean State Physicians Health Plan, Inc. v. Blue Cross \& Blue Shield of R.I., 692 F. Supp. 52 (D.R.I. 1988).

12. See infra text accompanying notes 26-42.

13. See Iglehart, Medicaid Tums to Prepaid Managed Care, 308 New Eng. J. Med. 976, 976 (1983) ("Medicaid has grown to become the single largest and fastest growing item in most state budgets."). For an account of difficulties encountered with the Massachusetts managed care program for AFDC 
capitation fee. ${ }^{14}$ Since medical expenses are generally financed through the medium of insurance, the article assumes that medical care will be "managed" in a health insurance context. It also assumes that the product at issue, insured health services, spans two historically distinct levels of competition. The product's hybrid characteristics derive from both health insurance and medical service markets. Even though in one sense managed care plans, particularly prepaid offerings, have created a distinct new product market of their own, ${ }^{15}$ in reality they continue to compete directly with traditional insurers. To a lesser extent they also compete in provider markets with traditional fee-for-service medicine itself. ${ }^{16}$

Patients are gradually losing the ability to choose the providers who actually care for them as these powerful managed care plans proliferate and consolidate their influence; ${ }^{17}$ competitive conditions in the markets for both health services and insurance could ultimately be threatened by some of these changes. The Seventh Circuit explicitly acknowledged that point in Ball Memorial Hospital, Inc. v. Mutual Hospital Insurance, Inc., ${ }^{18}$ one of the cases analyzed in this article. ${ }^{19}$ "Patients and employers must choose among . . . [managed care] plans. Once they have chosen a plan, they may have little control over their care. Choosing a PPO plan[ $\left.{ }^{20}\right]$ or $\mathrm{HMO}\left[{ }^{21}\right]$ may [in

families, see Prottas \& Handler, The Complexities of Managed Care: Operating a Voluntary System, $12 \mathrm{~J}$. Health Pol. Pol'y \& L. 253 (1987).

Medicare makes lump-sum payments for inpatient hospital care pursuant to Diagnosis Related Groupings ("DRG's"), a closed-end payment mechanism for managing care. Medicare has also recently proposed paying physicians on a preferred provider basis for medical services. N.Y. Times, Oct. 13, 1987, § 1 at 1 , col. 4 . In addition, the Medicare program permits beneficiaries to enroll in qualified health maintenance organizations ("HMO's"). 42 C.F.R. \$ 417.201.

14. Typical prepaid plans include preferred provider organizations ("PPO's") and HMO's. See infra text accompanying notes 29-33.

15. Cf. Colton \& Rubin, Traditional Antitrust Analysis and Alternative Health Care Delivery Systems: Can Old Tools Harvest New Answers?, 17 J. RePrints for ANTITRUST L. \& ECON. 273, 310 (1981) (suggesting cluster of services analysis in the health care industry when " $[\mathrm{t}]$ he product market is sufficiently distinct so that there are no substitutable products available in other markets."); Pennsylvania Dental Ass'n v. Medical Serv. Ass'n, 574 F. Supp. 457, $471-72$ (M.D. Pa. 1983) ("Blue Shield's system of participating doctors and direct provider payment is not so obviously unique as to render other forms of dental plans non-competitive with Blue Shield from a potential customer's perspective."), aff'd, 745 F.2d 248 (3d Cir. 1984), cert. denied, 471 U.S. 1016 (1985).

16. Alpert \& McCarthy, Beyond Goldfarb: Applying Traditional Antitrust Analysis to Changing Health Markets, 29 ANTITRUST BulL. 165, 186 (1984).

17. See, e.g., American Med. Care \& Rev. Ass'n, Directory of Preferred Provider Organizations and the Industry Report on PPO Development, Tables 9, 10, at xxii, xxiii (1987), reprinted in 20 Internal Med. News No. 18, at 3, col. 2 (1987). These tables show 654,560 physician contracts and 10,543 hospital contracts with managed care PPO's as of June 1987. Many providers have, however, contracted with more than one PPO. For the definition of PPO's, see infra note 20.

18. 784 F.2d 1325 (7th Cir. 1986).

19. See infra text accompanying notes $168-89$.

20. A PPO is a preferred provider organization, wherein subscribers have financial incentives to get medical care from "preferred" providers who render care for discounted fees. See generally T. Fox \& A. Weisman, Preferred Provider Organizations (1984); Group Health ass'n Am., Inc., New Health Care Systems: HMO's \& Beyond (1986); Enthoven, An Economic Analysis of the "Preferred Provider Organization " Concept, in The New HealthCare Market: A Guide to PPO's for Purchasers, Payors and Providers 94 (P. Boland ed. 1985). See also infra text accompanying note 35.

21. An HMO is a health maintenance organization, wherein subscribers are covered for care delivered by HMO providers only, except in emergencies or when no HMO provider is qualified to deliver care needed by the subscriber. See infra text accompanying notes 29-32. 
economic reality] lock a person in to a particular provider." 22 This article advocates that potential diminution of competition among individual providers, and derivatively among insurers, should be central to antitrust analysis of the vertical restraints imposed by powerful insurers. ${ }^{23}$

III

\section{Managed Care Organizational Forms and Operational Methods}

Fee-for-service health insurance, which originally operated primarily as a cost-pass-through financing device, often led to unnecessary medical expenditures. ${ }^{24}$ Fee-for-service insurers simply compensated providers directly for units of care as insureds consumed them, or they reimbursed subscribers with indemnity coverage for the cost of medical services they received. Historically these insurers gave little or no attention to managing the care they funded. They simply calculated premiums on the basis of projected use, regardless of whether services were medically necessary. ${ }^{25}$ Providers thus had clear financial incentives to deliver excess units of care. Benefits were as broad and as deep as subscribers were willing to purchase, so coinsurance, deductibles, and dollar limits on total coverage were not uncommon.

Prepaid health insurance plans, under which a wide range of health services is completely funded for a fixed premium paid in advance, were

22. 784 F.2d at 1330. The Seventh Circuit's contemporaneous opinion in Fishman v. Wirtz, 807 F.2d 520, 536 ( 7 th Cir. 1986), makes clear, moreover, that injury to the competitive process is sufficient to injure competition within the meaning of the antitrust laws ("A healthy and unimpaired competitive process is presumed to be in the consumer interest."). The opinion also held that plaintiffs have no burden "to isolate and demonstrate the consumer impact of a particular antitrust violation not directed at the consumer level." Id.

See also Brunswick Corp. v. Pueblo Bowl-O-Mat, 429 U.S. 477, 488 (1977) (antitrust laws enacted to protect competition, not competitors); Havoco of Am. Ltd. v. Shell Oil Co., 626 F.2d 549, 558 (7th Cir. 1980) (issue is whether there is injury to competition at any level, not whether consumers are directly affected by challenged conduct).

23. As the Court of Appeals for the First Circuit has noted, "the subject matter of . . Medical costs . . is an area of great complexity where more than solely economic values are at stake." Kartell v. Blue Shield of Mass., 749 F.2d 922, 931 (1984).

For commentators advocating that economic efficiency not be the sole concern of antitrust, see Brodley, The Economic Goals of Antitrust Efficiency, Consumer Welfare, and Technological Progress, 62 N.Y.U. L. Rev. 1020 (1987); Fox \& Sullivan, Antitrust-Retrospective and Prospective: Where Are We Coming From? Where Are We Going?, 62 N.Y.U. L. Rev. 936 (1987); Fox, The Modernization of Antitrust: A New Equilibrium, 66 CoRnell L. Rev. 1140 (1981); Hovenkamp, Distributive Justice and the Antitrust Laws, 51 Geo. WASH. L. Rev. 1 (1982); Lande, Wealth Transfers as the Original and Primary Concern of Antitrust: The Efficiency Interpretation Challenged, 34 Hastings L.J. 65 (1982); Pitofsky, The Political Content of Antitrust, 127 U. PA. I. Rev. 1051 (1979).

24. See generally S. Law, Blue Cross: What Went Wrong? 6-13 (2d ed. 1976) (recounting how individuals were originally directed to save for expensive medical services and the obstacles facing introduction of comprehensive prepaid plans).

25. See Kallstrom, Health Care Cost Control by Third Party Payors: Fee Schedules and the Sherman Act, 1978 Duke L.J. 645, 647-48 (customary medical practice gives providers no incentives to restrain excessive care or fees); Posner, Regulatory Aspects of National Health Insurance Plans, 39 U. CHI. L. REv. 1,5 (1971) (medical care system is practically given a blank check for its services). 
designed to function differently. ${ }^{26}$ Prepaid plans have always managed care in order to be more cost-effective than fee-for-service medicine; they risk financial catastrophe if they underwrite comprehensive but unmonitored medical expenses for a single fixed premium. Although there is growing controversy over this point, ${ }^{27}$ well-managed prepaid plans theoretically fund a full range of comprehensive health services more economically than can feefor-service insurers, because the cost-containment mechanisms they employ tend to weed out unnecessary care. ${ }^{28}$

Health maintenance organizations ("HMO's") ${ }^{29}$ such as the KaiserPermanente Group ${ }^{30}$ are the prototype prepaid plans, and in traditional closed-panel HMO's, insurance and provider functions are technically merged. ${ }^{31}$ Salaried physicians and allied health personnel provide basic medical services freed from temptation to receive extra income for superfluous care. Hospitalization takes place either in HMO-owned facilities or in hospitals contracting to comply with the HMO's cost-containment directives. In open-panel HMO's, on the other hand, the independent contractor physicians who provide medical services are unsalaried. Doctors are usually compensated either on a capitation basis for each HMO patient in their care, or on a discounted fee-for-service basis, with incentives to discourage excess utilization built into the reimbursement formula. ${ }^{32}$

Preferred provider organizations ("PPO's") are an important variation on the prepaid health insurance theme, and combine features of both HMO and

26. See generally D. Cowan, Preferred Provider Organizations 5-9 (1984); Attorneys and Physicians Examine Preferred Provider Organizations (J. Waxman ed. 1984); Nat'l Health Law. Ass'n, An Intróduction to Alternative Delivery Mechanisms (Anderson ed. 1986).

27. See, e.g., Kramon, Insurance Rates for Health Care Increase Sharply, N.Y. Times, Jan. 12, 1988, at 1 , col. 6, D5, cols. 1,3 .

28. See Symposium, 10 J. Health Pol., Pol'y \& L. (Winter 1986); Arnould, Debrock \& Pollard, Do HMO's Produce Specific Services More Efficiently?, 21 Inquiry 243 (1984). See also Hillman, Financial Incentives for Physicians in HMO's, 317 NEw ENG. J. MED. 1743 (1987).

29. The federal HMO Act defines an HMO broadly to include the activities of many related entities offering prepaid health care, such as PPO's. 42 U.S.C. $\S 300 \mathrm{e}(\mathrm{a})(\mathrm{d})$ (1982). Other broad definitions of HMO's include any organization which "assumes a contractual responsibility to provide or assure the delivery of health services to a voluntarily enrolled population that pays a fixed premium ...." Luft, How Do Health-Maintenance Organizations Achieve Their "Savings"?, 298 NEw ENG. J. MED. 1336,1336 (1978) (citation omitted).

For purposes of this article, however, a more narrow, traditional definition of HMO's is used. As used here, the term encompasses primarily closed-panel, salaried, group-practice models and their corporate sponsors.

30. The Kaiser-Permanente Group, in existence for many decades, is the largest HMO network in the United States. See Note, Nonprofit Health Maintenance Organization Pricing Policies and the Scope of the Robinson-Patman Price Discrimination Act, 16 Seton Hall L. Rev. 220, 222 (1986). In 1983 the Kaiser program had more than 4.3 million members, accounting for more than $36 \%$ of the nation's entire HMO membership. Id. at 222 n.17.

31. See generally Gittler, Hospital Cost Containment in Iowa: A Guide for State Public Policymakers, 69 IOWA L. REv. 1263, 1271 (1984) (HMO's effectively combine provider and insurance functions).

32. See generally Hillman, supra note 28, at 1743 ("Sixty-seven percent of plans with capitationbased arrangements and 82 percent of plans with fee-for-service arrangements withhold a percentage of their physicians' income against potential deficits . . . ."). 
fee-for-service insurance coverage. ${ }^{33}$ If the PPO insured receives care from a "preferred" provider, who has contracted with the PPO to render services subject to managed care constraints, the insurance premium covers the full costs of care. If instead the insured chooses to obtain care from a noncontracting provider, PPO coverage functions as indemnity insurance. This means that insured patients have to pay their non-PPO provider bills directly. They will usually be reimbursed for only part of that expense, however, because non-preferred provider charges ordinarily exceed those allowed by the PPO.

Other variations on the prepaid health insurance theme abound, ${ }^{34}$ but HMO's and PPO's constitute the most important prepaid organizational forms for purposes of this article. The savings many of these plans have achieved by managing care to eliminate unnecessary costs have enabled them to compete successfully against traditional fee-for-service health insurance coverage in many areas. ${ }^{35}$ Many plans reimbursing on a fee-for-service basis have been compelled to adopt aggressive techniques for managing care themselves in order to remain competitive. ${ }^{36}$ It is thus not uncommon, for example, to see Blue Cross/Blue Shield fee-for-service plans beginning to take a hard line on such cost control issues as second opinions. ${ }^{37}$

Inherent in the basic concept of managed care are mandatory and more or less aggressive cost-containment measures, as opposed to the passive costpass-through methods of financing traditional health insurance packages. ${ }^{38}$ These cost-containment devices impose vertical constraints on provider autonomy. In addition to second opinion requirements, they include mandatory utilization review, restrictions on hospital lengths of stay, discounted reimbursement for preferred providers, and lump-sum payments for specific diagnoses, along with a wide range of other cost-control

33. Demkovich, "PPO"-Three Letters That May Form One Answer to Runaway Health Costs, 15 NAT'L J. 1176, 1176 (1983) (recognizing and delineating differences and similarities between PPO's, HMO's, and fee-for-service arrangements).

34. See generally Kopit \& Klothen, Antitust Implications of the Activities of Health Maintenance Organizations, 25 ST. LouIs L. REv. 247, 249 (1981) (description of IPA's-individual practice associations-which generally function as open-panel, fee-for-service prepaid group health plans).

35. Frank \& Welch, The Competitive Effects of HMO's: A Review of the Evidence, 22 INQUIRY 148 (1985). Relatively few HMO's existed until the mid-1970's, when federal legislation offering such advantages as guaranteed loans and government financing for HMO development and operating costs spurred growth of qualifying plans. 42 U.S.C. $\$ \S 300 \mathrm{e}-3(\mathrm{~b}), 300 \mathrm{e}-4$ (1984). Moreover, employers with 25 or morc cmployees must offer the option of membership in a locally qualifying $\mathrm{HMO}$ if the employer offers any health insurance benefits at all. 42 U.S.C. $\$ 300 \mathrm{e}-9$ (1982).

36. See Wenzel, Managing Managed Care, 28 Consultant 105, 107 (Apr. 1988) (" $[t]$ he old, pure FFS that we knew ten years ago is probably already dead and . . . [has] been replaced by a managed FFS system ....."); Gallivan \& Traska, Blues Eye Major Conversion to Managed Care, 60 HospIrals 62 (1986) (describing rapid growth of Blue managed care plans nationwide).

37. Blue Cross/Blue Shield's Master Health Plus plan in Massachusetts, for example, requires second opinions before paying for seven common non-emergency procedures.

38. Under traditional indemnity insurance programs, the patient pays for itemized services directly and applies to the insurer for reimbursement. Originally, Blue Cross and Blue Shield indemnity plans guaranteed full payments to participating hospitals for services provided to its subscribers with the provider applying for payment directly. See S. LAw, supra note 24 , at 9 (describing development of Blue Cross and Blue Shield plans and systems). 
mechanisms. $^{39}$ Restraints useful for more exclusionary anticompetitive purposes also exist, such as exclusive dealing contracts and most-favorednation clauses. ${ }^{40}$ Such clauses require providers to offer powerful insurers discounts identical to those granted their competitors. These vertical restraints can be visualized as follows:

\section{Diagram $1^{41}$}

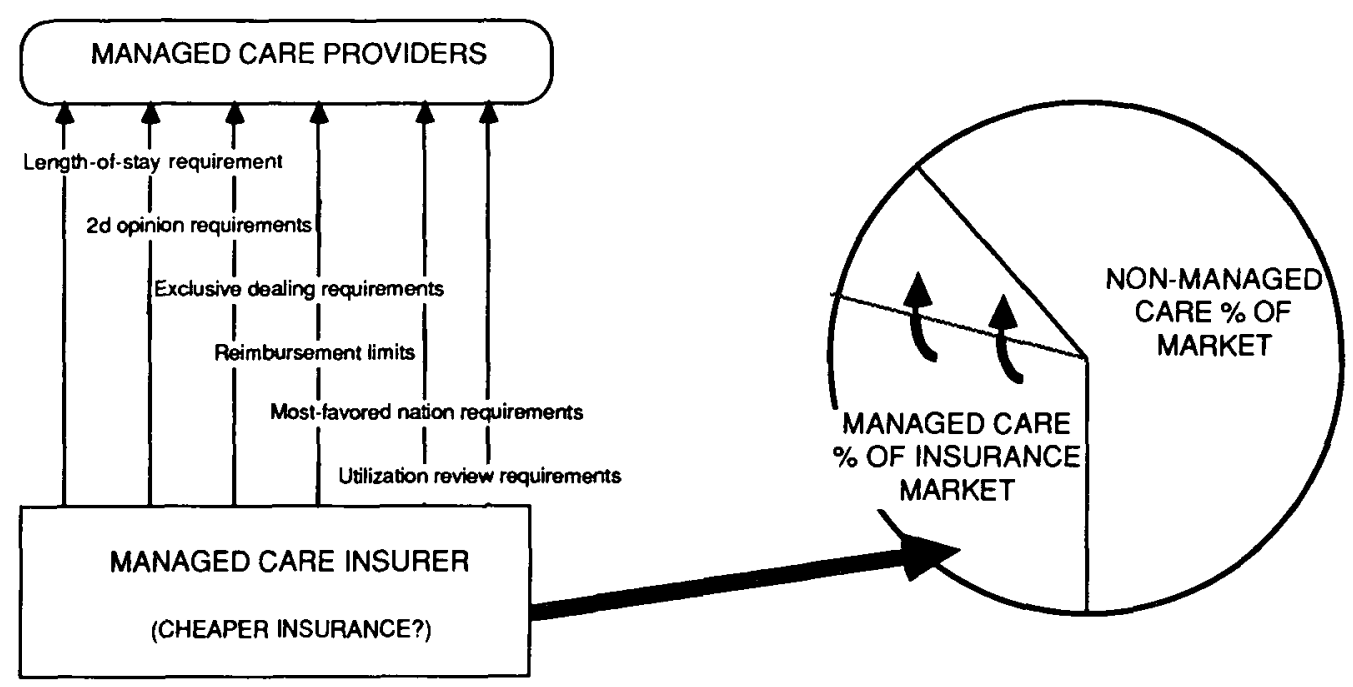

MANAGED CARE HELPS INSURER

TO CAPTURE LARGER MARKET SHARE

BY CONTAINING COSTS AND THUS

FACILITATING MORE COMPETITIVE PREMIUMS

Diagramming relationships among the parties affected by managed care arrangements also helps to clarify the impact of managed care's vertical

39. See generally Richards, Antitrust and the Future of Cost Containment Efforts in the Health Profession, 62 Neb. L. Rev. 49 (1983) (tracing the development of HMO's and their contributions to cost containment efforts).

40. See infra text accompanying notes 201-06.

41. One could argue that the medical service delivery component ought to be considered downstream because it is closest to the patient, rather than upstream as an input to the health insurance product. For purposes of analysis in this article the precise juxtaposition is not particularly relevant. On this point, with respect to diagramming vertical relationships, see Krattenmaker \& Salop, Anticompetitive Exclusion: Raising Rivals ' Costs to Achieve Power Over Price, 96 Y ALE L.J. 209, 226-27 (1986). 
restraints on competition in both health insurance and medical service markets. ${ }^{42}$ Assuming that the patient receives health insurance coverage through employment, the parties relate to one another in simplified form as follows:
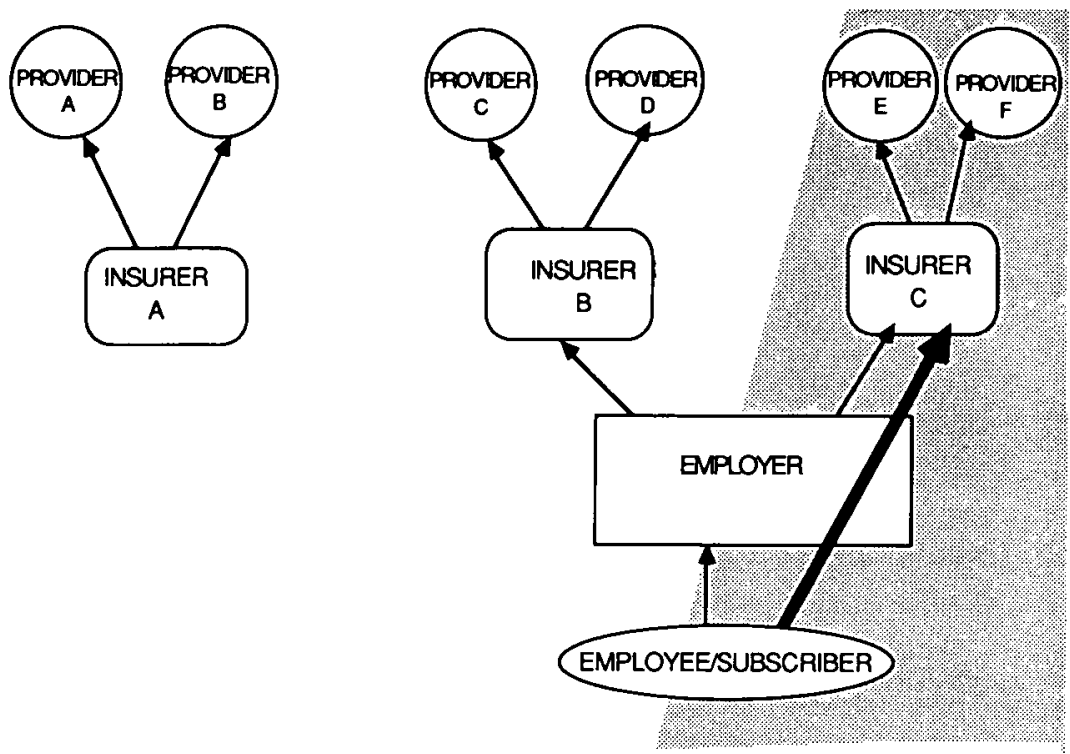

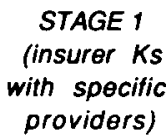

STAGE 2 (employer Ks with specific insurers

STAGE 3 (employee chooses specific insurer)

\section{EMPLOYEE'S ULTIMATE CHOICE (BETWEEN E \& F) IS NARROWED AT EACH STAGE OF THE "PURCHASING" DECISION}

Diagram 2 assumes that the managed care "product" is a package consisting of insured health services. This package includes-in a more or less theoretical sense, depending on the plan-both the service itself and the financing mechanism that pays for it. The diagram illuminates the fact that the choice of medical services in the typical managed care plan, whether or not the insurer and provider functions have been formally integrated, goes through three stages. Initially the insurer or other financer packages the plan by contracting with specific providers who agree to abide by its costcontainment directives. The employer then selects a specific group plan or plans to offer its employees. Finally, the patient chooses, first among whatever plans are offered through employment, and then among the providers contracting to render services through the scheme he has chosen. In effect, three separate "purchases" of health services are involved, the first two of which narrow the range of choice available to the ultimate user at the

42. On the changes in traditional relationships among insurers, physicians, and patients, see generally The Upheaval in Health Care, Bus. WeEk, July 25, 1983, at 44.

43. Providers have been depicted upstream and insurers downstream in this diagram to show how the choice of providers progressively narrows at each step of the purchasing process. 
third stage.44 Antitrust analysis should be sensitive to the impact of challenged behavior on competition at each one of these separate phases.

Managed care's cost-containment mechanisms theoretically permit insurers to hold the line on premium increases and have spawned the relatively new and fiercely competitive current market environment for health insurance. Employers now function as knowledgeable, cost-conscious consumer-surrogates for the purchase of health services through their managed care offerings. HealthPlan Management Services, a subsidiary of John Hancock Mutual Life Insurance Co., even offers a consulting service to help employers prune out the less efficient managed care plans they already offer their employees. ${ }^{45}$ These developments have forced health insurers to pressure providers to focus intently on the bottom line; when cost savings are unsatisfactory, many large employers will simply self-insure and administer their own managed care plans. ${ }^{46}$

Ironically, the increasing sophistication of employers as surrogate medical service purchasers for their employees threatens to restrict patient choice as to the insured medical care ultimately received. By forcing doctors and hospitals to spar among themselves for insurer and therefore employer favor, competition among many providers for patient approval is beginning to diminish. The extent of provider choice open to insured patients is thus gradually eroding in many areas, as employers refuse to purchase group coverage that is not cost efficient for them. The insurance coverage employers retain often sharply limits the range of providers-and provider services-available to their insured employees as patients. ${ }^{47}$

The cost-containment features of managed care offerings can have other profound effects on competition in the market for health services. As preferred provider plans gain favor, excluded doctors and hospitals must compete for a shrinking pool of patients. The pool consists of those patients who are willing to self-pay, or who are covered either by indemnity insurance, by preferred provider plans in which "non-preferred" providers are eligible to participate on less favorable terms, or by plans in which there are no "preferred" providers at all. The problem excluded providers face is

44. The patient always has the option, of course, of forgoing insurance coverage and purchasing health care services out-of-pocket. Cf. Rosenblatt, Health Care, Markets, and Democratic Values, 34 VAND. L. REV. 1067, 1085-88 (1981) (warning that health care consumers-patients-are neither willing nor capable of actively refusing even expensive or inefficient insurance plans and risking out-of-pocket payments).

45. Meyer, New Insurance Service Helps Employers Purge HMO's, Am. Med. News, July 17, 1987, at 93, col. 1 .

46. Self-insured employers often purchase stop-loss coverage to limit their liability by providing, in essence, catastrophic illness protection for their workers.

47. See, e.g., Honeywell Calling Shots on Transplants, Am. Med. News, Jan. 8, 1988, at 1, col. 1 (insured employees limited to specific medical centers for (ransplantation services). Insured employees are not actually prevented from using non-plan providers, but since they must pay for at least part of non-participator services out-of-pocket, strong economic incentives to use doctors and hospitals contracting with the plan exist. See, e.g., discussion in Blue Shield of Va. v. McCready, 457 U.S. 465, 483-84 (1982) ("[S]ubscribers were compelled to choose between visiting a psychologist [rather than a psychiatrist, approved by Blue Shield] and forfeiting reimbursement, or receiving reimbursement by forgoing treatment by the practitioner of their choice.") (emphasis added). 
exacerbated by the nation's current oversupply of physicians ${ }^{48}$ and hospital beds, ${ }^{49}$ and by the growing availability of physician-substitutes and outpatient alternatives to hospitalization. Moreover, the cost-containment directives of managed care plans often engender concerted provider resistance, which in turn raises its own set of antitrust problems. ${ }^{50}$

The current popularity of managed care programs stems from the extensively documented ${ }^{51}$ escalating spiral of health care costs over the past two decades.52 Employers subsidize the bulk of private health insurance purchases through employee group health plans, and expensive new technology and other factors have driven the percentage of overall business costs consumed by health insurance premiums sharply upward.53 Employers have thus sought to reduce premium costs in order to remain competitive with both domestic and foreign business rivals.

In addition, federal, state, and local governments fund approximately 40 percent of the country's total health care expenditures. ${ }^{54}$ Governmental programs for controlling the costs of medical services thus constitute survival strategies for revenue-conscious politicians and civil servants. The vertical restraints of managed care are-at least in theory-tailor-made to respond to public and private sector distress about the rising monetary and political costs of financing health services for employees and for beneficiaries of government programs. ${ }^{55}$

48. Law \& Ensminger, Negotiating Physicians 'Fees: Individual Patients or Society? (A Case Study in Federalism), 61 N.Y.U. L. REv. 1,18 n.94 (1986). Some economists maintain that the problem is one of maldistribution rather than of an excess supply of physicians. See, e.g., P. Feldstein, Health Care ECONOMics 367 (2d ed. 1983).

There are signs that the supply of physicians may, however, contract in the future. Applications to medical school have declined from a high of 42,624 in 1974-75 (for 14,963 places) to 31,323 in 1986-87 (for 16,779 places). Am. Med. News, Feb. 19, 1988, at 3, col. 2. In 1975, one out of every three applicants to medical school was admitted, whereas in 1987 there were only 1.6 applicants for each available spot. Id. The American College of Physicians has issued a policy statement calling for medical schools to reduce enrollments by $6 \%$ to $12 \%$ over the next six years. Id. at 3 , col. 1 .

Regulatory and economic constraints on physician autonomy, caps on physician income, and problems engendered by the AIDS epidemic have all combined to make medicine a less attractive career choice than it once was. Cf., Trager, AIDS Chasing Away Budding M.D.s? No, Say Educators, Med. Trib., Apr. 14, 1988, at 3, col. 1 .

49. In 1986, U.S. hospitals had an overall occupancy rate of only $68.4 \%$. AMERICAN HoSP. Ass' ${ }^{\prime}$, Hospital Statistics 1987, 12 (1987).

50. See, e.g., FTC v. Indiana Fed'n of Dentists, 476 U.S. 447 (1986) (dentists refused to submit xrays required for prior approval of "big ticket" dental expenditures); In re Michigan State Med. Soc'y, 44 Antitrust \& Trade Reg. Rep. 426 (1983) (respondent, a professional organization composed of $80 \%$ of Michigan's physicians, engaged in coercive conduct to influence third party reimbursement policies).

51. See, e.g., P. Feldstein, supra note 48, at 32-76.

52. Most analysts point to the passage of the federal Medicare and Medicaid programs, titles 18 and 19 of the Social Security Act of 1965, as the starting point for the current inflationary spiral in health care. Both programs were originally cost-based and more or less open-ended in terms of the dollar volume of health care services available to eligible beneficiaries.

53. Cf. Schatz, The AIDS Insurance Crisis: Underwriting or Overreaching?, 100 Harv. L. Rev. 1782 , 1798 (1987) (medical and technological advances contribute to the increasingly severe problem of "uninsurability" in the U.S.).

54. See 8 Health Care Fin. Rev., Fall 1986, Table 4, at 16.

55. For example, the Medicare program offers its beneficiaries the managed care option of enrolling in certain qualified HMO's. 42 C.F.R. $\$ 417.201$. See also A. Enthoven, Health Plan: The 
Managed care programs need providers willing to cooperate with a health insurance scheme's cost-containment directives. ${ }^{56}$ This means that hospitals and doctors ${ }^{57}$ must be organized, however loosely, into groupings that accept the particular plan's general cost-containment methodologies. These participating providers in effect pay for the competitive advantage of securing patient referrals from the plans by agreeing to accept lower reimbursement and controls on their clinical autonomy. These provider groupings may or may not be completely integrated-in a corporate merger sense-with the managed care insurance entity itself, ${ }^{58}$ but they exemplify a trend that has transformed health care delivery systems all over the country. That trend is away from small, independent, medical service delivery units and toward more consolidated, cooperative, and presumably more efficient schemes for providing care. 59

The new organizational structures essential to the functioning of managed care schemes have resulted in horizontal, vertical, and geographical alliances previously quite rare in the health industry. ${ }^{60}$ On the horizontal plane, competing physicians and hospitals participating in the same managed care plan often discover, for example, that price can no longer be an element of potential competition among them. ${ }^{61}$ Moreover, the plan's methodology for arriving at its pricing arrangements may present antitrust pitfalls if competing providers are too closely involved in negotiations that produce fee schedules. ${ }^{62}$

Only Practical Solution to the Soaring Cost of Medical Care xxiv (1980) ("[T]he principles of fair economic competition would at least point the health care system in the right direction-toward organized systems with built-in incentives for economy and consumer satisfaction."). For a recent study concluding that "neither competition [via HMO's] nor regulation had a significant impact in reducing overall hospital costs," see Merrill \& McLaughlin, Competition Versus Regulation: Some Empirical Evidence, $10 \mathrm{~J}$. Health Pol. Pol'y \& L. 613 (1985); $c f$. Goldberg \& Greenberg, The Determinants of HMO Enrollment and Growth, HeAlTh SERV. Res. 16, 421-38 (Apr. 1981).

56. For a description of the most common cost-containment measures in managed care plans, see supra text accompanying notes 39-40.

57. Some managed care plans offer some or all of a variety of allied health practitioner services in addition to those provided by physicians.

58. See infra text accompanying notes 68-72.

59. See generally AMA, Medical Groups in THE U.S. 1984 (1985).

60. See generally Martin \& Goddeeris, Policy and Structural Change in the Health Care Industry, 30 Antitrust Bull. 949 (1985). Hospital Corporation of America, the nation's largest for-profit hospital chain, was incorporated a mere 21 years ago, in 1968 . Light, supra note 2, at 38.

61. This assumes that medical providers really do-or could-compete on the basis of price. Historically, however, price has not been a dominant factor in patient decisions to purchase health services because widespread insurance coverage subsidizes the cost. Moreover, price information was not readily available to patients until recently because of ethical restrictions on physician advertising. FTC v. AMA, 94 F.T.C. 701 (1971), aff'd, 638 F.2d 443 (2d Cir. 1980), aff'd by equally divided Supreme Court, 455 U.S. 676 (1982), held that ethical prohibitions against physician advertising violate the antitrust laws. See generally Havighurst, Professional Restraints on Innovation in Health Care Financing, 1987 Duke L.J. 303.

62. See Arizona v. Maricopa County Medical Soc'y, 457 U.S. 332, 352-53 n.25 (1982) (The Court did not reach the question "whether an insurer may, consistent with the Sherman Act, fix the fee schedule and enter into bilateral contracts with individual doctors," but suggested that "such an agreement would be legal unless the plaintiffs could establish that a conspiracy among providers was at work."). 
On the vertical plane, insurance company sponsorship of managed care plans can raise antitrust issues, under both sections 1 and 2 of the Sherman Act, with respect to competition in the markets for health services and health insurance. ${ }^{63}$ Providers eligible to deliver care under these plans often resent having to negotiate with powerful insurers that have large pre-existing subscriber populations, and frequently allege that they are the victims of monopolistic or monopsonistic tactics. ${ }^{64}$ Established managed care insurers like the Blue Cross and Blue Shield corporations are particularly vulnerable to antitrust challenge when, in addition to competing in insurance markets, they attempt to compete in medical service markets directly via their own prepaid offerings. They present a tempting target for antitrust scrutiny when they attempt to use their economic leverage as traditional insurers to exclude competitors in provider markets. Two recent federal court juries have condemned such behavior. ${ }^{65}$ In one case, although a Rhode Island jury found the Blues guilty of engaging in monopolistic conduct for imposing economic penalties on participating providers who contracted with competing managed care plans, a motion for judgment notwithstanding the verdict was granted nine months later. ${ }^{6} 6$

As previously demonstrated, dominant health insurers are major middlemen-buyers in provider markets; as such they theoretically have power to exclude-or at least to harm-rivals at both levels of competition. This dual market impact of managed care operations, when combined with the fact that insurer, employer, and patient can each in some sense be considered the purchaser of medical services in managed care environments, presents a special challenge for antitrust analysis. ${ }^{67}$

63. See infra text accompanying notes 92-99.

64. See, e.g., Kartell v. Blue Shield of Mass., 749 F.2d 922 (1st Cir. 1984), cert. denied, 471 U.S. 1029 (1985); Ball Memorial Hosp. v. Mutual Hosp. Ins., 784 F.2d 1325 (7th Cir. 1986), reh' $g$ denied, 788 F.2d 1223 (7th Cir. 1986).

For a description of bitter current controversies between providers and powerful insurers, see McCann, Blues, Hospitals in "Shopping War", Med. Trib., July 15, 1987, at 1, col. 2 (highlighting controversies between hospitals and powerful insurers); Apgar, Out of the Blues, Mass. Med., July-Aug. 1987, at 30 (focusing on conflicts between physicians and powerful insurers).

65. Reazin v. Blue Cross \& Blue Shield of Kan., 663 F. Supp. 1360 (D. Kan. 1987); Ocean State Physicians Health Plan, Inc. v. Blue Cross \& Blue Shield of R.I., No. 86-0598 (D.R.I. Oct. 24, 1987). See Baker, Vertical Restraints Among Hospitals, Physicians and Health Insurers that Raise Rivals' Costs, 14 AM. J. L. MED. 147 (1988).

66. Ocean State Physicians Health Plan, Inc. v. Blue Cross \& Blue Shield of R.I., 692 F. Supp. 52 (D.R.I. 1988). See infra text accompanying notes 191-209.

67. The challenge is intensified by the relatively unusual and extensively chronicled features of competition in the health service industry. The market for health services differs from the ideal competitive model for many well-known reasons. Among these are a serious information problem compromising the ability of patients to make rational economic choices, and the moral hazard created by widespread health insurance coverage. The pressures of defensive medicine also prompt many physicians to deliver more services than may be medically indicated in an effort to limit their own exposure to malpractice liability. Moreover, favorable tax treatment for many health and health insurance expenditures, and the technological imperative whereby both physicians and patients often uncritically equate more health expenditures with better health care, combine to undermine a true competitive market in health care. The nonprofit form through which many institutional providers deliver health services also puts a non-commercial gloss on profit-maximizing behavior. Finally, regulatory mechanisms such as licensure, certificate-of-need, rate-setting, and peer-review 


\section{IV \\ Organizational Structure and Vertical Restraints}

Closed-panel HMO's with salaried physicians constitute managed care examples of complete vertical integration ${ }^{68}$ because both the insurance and service delivery functions are provided by the same corporate entity. In fullyintegrated managed care operations, no question of offending section 1 of the Sherman Act through the use of vertical restraints usually arises, for a single corporate entity cannot "conspire" with itself to restrain trade.69 Section 2 monopolization or monopsonization charges can always be made, however, if the entity has or could have market power at either of the levels of competition in which it does business. ${ }^{70}$

Open-panel managed care plans using independent contractor physicians-such as many IPA's and PPO's, as well as fee-for-service Blue Cross/Blue Shield and some indemnity schemes-also impose vertical restraints. No complete integration of the parties to the insurer-provider agreement in the corporate merger sense usually exists, however. ${ }^{71}$ Section 1

organizations contain normal competitive forces to a greater or lesser extent in the health industry. See generally Clark, Does the Nonprofit Form Fit the Hospital Industry?, 93 HaRv. L. Rev. 1416 (1980); McClure, Structure and Incentive Problems in Economic Regulation of Medical Care, 59 Milbank Memorial Fund Q. 107 (1981); Pauly, Is Medical Care Different?, in FTC, Competition in the Health Care Sector, Proceedings of a Conference Sponsored by the Bureau of Economics 19 (1978). See also Langer, The Role of Antitrust Enforcement in a Minimum Benefits-Procompetitive National Health Plan, 28 ST. LouIS U. L.J. 311, 314-17 (1984).

The Supreme Court has stated that the unusual features of health care markets are insufficient reason to depart from a rule of per se illegality for maximum price-fixing agreements among horizontally competing physicians. Arizona v. Maricopa County Medical Soc'y, 457 U.S. 332, 349 (1982). However, it has taken a more relaxed attitude toward boycotting as a per se offense in the health care context. FTC v. Indiana Fed'n of Dentists, 476 U.S. 447 (1986).

68. Vertical integration has been defined as "the inclusion within a single firm of two or more stages in the production and distribution of an end-product." 3 P. AREEDA \& D. TURNER, ANTITrust LAw 9723 , at 194-95 (1978). Posner and Easterbrook take a somewhat more eclectic view, defining it broadly as "any production within the firm of an input into or complement to the firm's output" or narrowly as "union within one firm of conventionally distinct states of production and distribution." R. Posner \& F. Easterbrook, Antitrust Cases, Economic Notes and Other Materials 869 (1981).

On the theory that concepts appropriate to analysis of vertical mergers have improperly been applied to the evaluation of vertical restraints, see Scherer, The Economics of Vertical Restraints, 52 ANTITRUST L.J. 687 (1983).

69. Copperweld Corp. v. Independence Tube Corp., 467 U.S. 752, 769 (1984) (and cases there noted) ("[O]fficers and employees of the same firm do not provide the plurality of actors imperative for a $\$ 1$ conspiracy.").

70. 3 P. Areeda \& D. Turner, supra note 68 , at $19728 \mathrm{a}-\mathrm{c}$, at 228-34 (monopolist who operates in two market levels may violate the Sherman Act if it engages in purposeful predatory activities such as price squeezing, supply squeezing, or pricing below marginal cost).

71. This article does not specifically address corporate mergers of health industry players previously operating independently at different levels of competition, although true corporate mergers can present serious antitrust problems of their own. On vertical mergers generally, see L. Sullivan, Antitrust $\S 210$, at 657-69 (1977).

This article is concerned primarily with vertical arrangements short of full corporate integration, and with the formation of new subsidiaries or parents at a different level of competition by powerful health care providers or insurers. On exclusive dealing arrangements generally see id. at 471-95.

For the Justice Department's generally laissez-faire position toward non-price vertical restraints, see DOJ Vertical Restraints Guidelines, 50 Fed. Reg. 31,6263 (1985). For the National 
conspiracies could thus exist in open-panel systems, in addition to section 2 monopolistic and/or monopsonistic behavior. Insurers and providers in other managed care situations can be partially integrated if all share at least some part of the risks and rewards of the venture. Partial integration provides some section 1 protection, if not complete immunity. ${ }^{72}$ In still other instances, insurer and providers entering into agreements with a particular plan may simply be independent contractors not bound to one another in any risk/profit sharing sense at all. Both section 1 and section 2 of the Sherman Act are thus theoretically available to police anticompetitive conduct associated with the vertical arrangements attendant to such unintegrated schemes.

\section{A. Vertical Pricing Arrangements}

The Supreme Court held flatly in Business Electronics Corporation $v$. Sharp Electronics Corporation that "a vertical restraint is not illegal per se unless it includes some agreement on price or price levels."73 Pricing arrangements for providers have thus received more thorough attention from antitrust commentators than has any other restraint relating to managed care. ${ }^{74}$ Much of this attention stems from the Supreme Court's opinion in Arizona $v$. Maricopa County Medical Society. ${ }^{75}$ That case applied the per se rule to a horizontal agreement among competing physicians, organized as a foundation for medical care, to abide by a maximum fee schedule. ${ }^{76}$ The agreement then functioned as a vertical restraint when the foundation marketed the services of its physician-members to health insurers as preferred providers. Members were presented as willing to be restrained by the foundation's reimbursement schedule as payment in full for services rendered to insureds. ${ }^{77}$

Unintegrated managed care offerings need standardized methodologies for compensating independent participating providers, but in the words of the Supreme Court, "if a fee schedule is . . . desirable, it is not necessary that the

\footnotetext{
Association of Attorneys General's less sanguine approach, see NAAG Adopts Alternative Guidelines to Govern Vertical Restraints of Trade, 49 Antitrust \& Trade Reg. Rep. (BNA) No. 1243, at 978 (1985).

72. Arizona v. Maricopa County Medical Soc'y, 457 U.S. 332, 356-57 (1982).

73. 56 U.S.L.W. 4387,4392 (1988).

74. See, e.g., Costilo \& Kazon, Preferred Provider Plans: Avoiding Problems of Horizontal Price-Fixing, 29 Antitrust Bull. 403 (1984); Greaney \& Sindelar, Physician-Sponsored Joint Ventures: An Antitrust Analysis of Preferred Provider Organizations, 18 Rutgers L.J. 513 (1987); Harrison, Price-Fixing, the Professions, and Ancillary Restraints: Coping with Maricopa County, 1982 U. IL.. L. REv. 925; Rich, PPO's and the Per Se Rule Against Price Fixing, 6 Whitrier L. Rev. 723 (1984); Walsh \& Feller, ProviderSponsored Alternative Health Care Delivery Systems: Reducing Antitrust Liability After Maricopa, 19 U. RicH. L. Rev. 207, $212-26$ (1985); Note, supra note 10; Note, Application of Per Se Rule Against Price Fixing to Doctors' Maximum Fee Schedules- Arizona v. Maricopa County Medical Society, 31 U. KAN. L. REv. 479 (1983); Commentary, Preferred Provider Organizations: Can the Doctors Do the Price Fixing?, 37 OKLA. L. REV. 733 (1984).

75. 457 U.S. 332 (1982).

76. Horizontal price-fixing has long been considered the core antitrust offense, thus meriting per se condemnation. See, e.g., Copperweld v. Independence Tube Corp., 467 U.S. 752, 768 (1983) (citing Northern Pacific R. Co. v. United States, 356 U.S. 1, 5 (1958)).

77. For the arguments against applying the per se rule to maximum price-fixing arrangements, see Easterbrook, Maximum Price-Fixing, 48 U. CHI. L. REv. 886 (1981).
} 
[competing] doctors do the price fixing."78 Much of the discussion in the literature has thus concentrated on analyzing how to insulate the fee setting process sufficiently to avoid subjecting providers to per se condemnation for horizontal price-fixing under section 1 . The literature also examines how fee setting can escape censure as an unreasonable restraint of trade among potential competitors once the per se hurdle has been cleared. ${ }^{79}$

Successful insulation of managed care pricing arrangements from allegations of horizontal conspiracy can take one or more of several forms. The simplest method is for competing providers to be completely divorced from the process by which acceptable fees are formulated, and thereafter for the plan to negotiate each independent provider's contract individually. In that way no allegation of a horizontal agreement among competitors on the issue of price can be made, and no antitrust violation, per se or otherwise, will be found under section $1 .{ }^{80}$ Many managed care offerings, however, are sponsored by provider groups anxious to meet the competitive threat posed by new and aggressive prepaid plans with unattractive terms of participation. Although provider-sponsored plans are riskier ventures from a section 1 perspective, they too can be structured to minimize charges of illegal anticompetitive behavior. ${ }^{81}$

The Supreme Court suggested in Maricopa that had the physicians involved in formulating the fee schedule been joined in some form of integrated joint venture, per se analysis would have been inappropriate. ${ }^{82}$ Integration in this context requires some type of risk-spreading among providers as a component of the scheme, but it does not necessarily entail a complete merger of previously separate entities. ${ }^{83}$

78. 457 U.S. at 352 (emphasis supplied).

79. See supra note 74 .

80. This assumes that providers will not agree among themselves to threaten to boycott plans that do not offer reimbursement on favorable terms, thus inviting antitrust condemnation on other grounds.

81. See generally Note, Vertical Integration Attempts by Health Care Providers: A One-Way Ticket to Antitrust Exposure?, 21 Gonz. L. Rev. 479 (1985-1986).

82. Arizona v. Maricopa County Medical Soc'y, 457 U.S. 332, 356-57 (1982).

83. See generally Greaney \& Sindelar, supra note 74. 


\section{B. Non-Price Vertical Restraints}

Non-price ${ }^{84}$ vertical agreements may have an indirect effect on price, but they are not generally considered illegal per se $^{85}$ unless tying is involved. ${ }^{86}$ Non-price vertical arrangements can have significant procompetitive effects, ${ }^{87}$ and for the last decade they have routinely been analyzed according to the rule of reason. ${ }^{88}$ Although they also have inherent potential to distort

84. The Supreme Court held resale price maintenance, a vertical price-fixing restraint, whereby the manufacturer or supplier of a product dictates the price at which the product is sold by independent retailers, per se illegal just after the turn of the century. Dr. Miles Med. Co. v. John D. Park \& Sons Co., 220 U.S. 373 (1911) (supplier selling to wholesaler may not restrict resale price by interfering with purchaser's pricing policies). See also Albrecht v. Herald Co., 390 U.S. 145, reh'g denied, 390 U.S. 1018 (1968) (maximum resale price maintenance illegal per se). Cf. United States v. Colgate \& Co., 250 U.S. 300 (1919) (manufacturer can refuse to do business with wholesalers who do not voluntarily adhere to prices suggested by manufacturer).

On resale restrictions generally, see L. Sullivan, supra note 73 , $\$ 142-149$, at 399-431. Cf. Pitofsky, In Defense of Discounters: The No-Frills Case for a Per Se Rule Against Vertical Price Fixing, 71 Geo. L.J. 1487 (1983). Cf. Monsanto Co. v. Spray-Rite Serv. Corp., 465 U.S. 752, reh' g denied, 466 U.S. 994 (1984); Calvani \& Berg, Resale Price Maintenance After Monsanto: A Doctrine Still at War with Itself, 1984 DUKE L.J. 1163.

85. Continental T.V., Inc. v. GTE Sylvania Inc., 433 U.S. 36 (1977).

86. The Supreme Court's recent decision in Jefferson Parish Hosp. Dist. No. 2 v. Hyde, 466 U.S. 2 (1984), involved an alleged illegal tying arrangement between a hospital and an anesthesiology group given an exclusive contract to provide anesthesiology services. Although the Court did not find the defendant possessed sufficient market power to commit the tying offense, it reaffirmed the potential application of per se illegality for tying in the health care context.

Tying is usually analyzed under $\S 1$ as an illegal agreement in restraint of trade-between sellers of the tying and the tied products-to force buyers to make a joint purchase, rather than as a $\S 2$ offense. Tying analysis is inapplicable to the vertical restraints of managed care plans, however. Feefor-service health insurers and PPO's do not use insurance market power to force the purchase of provider services which insureds would not otherwise choose to buy, although they may give economic incentives to do so. With HMO's and IPA's the consumer-patient specifically purchases a hybrid product consisting of service in the event of medical need plus payment, rather than the two separate products of health insurance and medical care. Therefore, no tie exists within the meaning of the per se offense.

87. The Department of Justice's Vertical Restraints Guidelines list five specific types of procompetitive effects fostered by vertical arrangements, plus a catch-all category of vertical agreements which can "improve product quality and safety and reduce transactions costs in numerous circumstances." 50 Fed. Reg. 31,6263, 6266-67 (1985). The guidelines go beyond current Supreme Court holdings in limiting application of the per se rule, and approach most vertical restraints with a presumption of legality. See Note, Permissible and Impermissible Vertical Restraints Under the Sherman Antitrust Act: Does "Justice" Care?, 63 Den. U.L. Rev. 127, 146-47 (1985).

The National Association of Attorneys General Guidelines set forth a narrower set of criteria, specifying diminution of intrabrand competition (leading to product enhancement), reduction of "free riding" (including vertical free riding), economies-of-scale, and facilitation of new product market entry as the procompetitive effects of vertical restraints. State Attorneys General Vertical Restraints Guidelines, Trade Reg. Rep. (CCH) \& 50,478, at 56,232-34 (1985). For a brief, thoughtful discussion of economic research on the free-rider issue, see Hay, The Free Rider Rationale and Vertical Restraints Analysis Reconsidered, 56 AnTITRUst L.J. 27 (1987).

88. Continental T.V., Inc. v. GTE Sylvania Inc., 433 U.S. 36 (1977); Jack Walters \& Sons Corp v. Morton Bldg., Inc., 737 F.2d 698 (7th Cir. 1984), cert. denied, 469 U.S. 1018 (1984); Quality Auto Body, Inc. v. Allstate Ins. Co., 660 F.2d 1 195, 1203 (7th Cir. 1981), cert. denied, 455 U.S. 1020 (1982). For ten years prior to 1977 most non-price vertical restraints were considered illegal per se in accordance with the Supreme Court's decision in Arnold v. Schwinn \& Co., 388 U.S. 365 (1967), which was subsequently overruled by GTE Sylvania Inc., 433 U.S. at 58. 
competitive markets, ${ }^{89}$ most such restraints have in fact easily survived under rule-of-reason analysis. ${ }^{90}$

The vertical aspects of managed care constraints present antitrust courts with a somewhat more difficult analytical dilemma when a powerful insurer is the manager because monopoly/monopsony related issues are raised in addition to garden variety section 1 problems. ${ }^{91}$ These section 2 problems apply to competition in both the health insurance and the medical service delivery markets. However, their potential for infecting two markets with misallocations of output have not been satisfactorily addressed in antitrust opinions thus far.

\section{V \\ Vertical Restraints and Powerful Insurers}

Certain managed care vertical restraints raise particularly troubling Sherman Act issues when imposed by powerful insurers because they can be manipulated to exclude competitors. Such controls on provider autonomy as the pricing terms, exclusive dealing and second opinion requirements, peerreview arrangements, limited panel restrictions, and most-favored-nation clauses found in many managed care plans all affect both insurer and provider markets. Each of these devices for managing care has procompetitive features, but when imposed by an insurer with a substantial market shareparticularly one who seeks also to compete as a provider through the mechanism of a prepaid plan-the exclusionary effect of the imposition might constitute a section 2 offense. If a conspiracy to impose the condition were found, the agreement could rise to the level of the per se offense of boycott,

89. Sometimes vertical agreements are challenged as de facto horizontal conspiracies in restraint of trade when one of the parties is allegedly controlled by competitors from a different level of competition. See, e.g., Ratino v. Medical Serv. of D.C. (Blue Shield), 718 F.2d 1260 (4th Cir. 1983); St. Bernard Gen. Hosp. v. Hospital Serv. Ass'n, 712 F.2d 978, 987 (5th Cir. 1983), cert. denied, 466 U.S. 970 (1984); Virginia Academy of Clinical Psychologists v. Blue Shield of Va., 624 F.2d 476 (4th Cir. 1980), cert. denied, 450 U.S. 916 (1981); Addino v. Genessee Valley Medical Care, Inc., 593 F. Supp. 892 (W.D.N.Y. 1984).

90. Commentators often note that the decision to apply rule-of-reason analysis (to a vertical restraint) is tantamount to a finding for the defendant. See, e.g., Redlich, The Burger Court and the Per Se Rule, 44 Alb. L. Rev. I, 53 (1979). See also Bork, The Rule of Reason and the Per Se Concept: Price Fixing and Market Division (pt. 2), 75 YALE L.J. 373, 399 (1966).

Recent economic studies suggest, however, that certain demand-increasing vertical restraints can reduce both allocative efficiency and consumer welfare. Comanor, Vertical Price-Fixing. Vertical Markel Restrictions, and the New Antitrust Policy, 98 HARv. L. Rev. 983, 999-1000 (1985); Scherer, supra note 68, at 701-04.

91. The term monopoly usually refers to a seller's "power to control prices or exclude competition." United States v. du Pont \& Co., 351 U.S. 377, 391 (1956). The term monopsony, on the other hand, describes "a situation in which the relevant market for a factor of production is dominated by a single purchaser." The Permian Basin Area Rate Cases, 390 U.S. 747, 794 n.64 (1968). These terms have been treated somewhat interchangeably in the cases. See, e.g., Kartell v. Blue Shield of Mass., 749 F.2d 922, 927-28 (1st Cir. 1984) (discussing buyer's market power in demanding or controlling prices as monopoly power without reference to monopsony).

This article takes the position, however, that antitrust analysis should be particularly alert to distinctions between the effects of monopoly and monopsony restraints on health service markets. Moreover, it should specifically address the further exacerbation of market distortions occurring when a monopolist possessing monopsony power seeks to compete in the market it monopsonizes. 
or its anticompetitive effects might simply outweigh the procompetitive ones under rule-of-reason analysis. In either of those cases the behavior would be considered illegal pursuant to section 1 .

In a plethora of recent lawsuits, the Blue Cross and/or Blue Shield organizations have evoked both section 1 and section 2 antitrust questions stemming from their historic role as the dominant seller of private health insurance in many jurisdictions. ${ }^{92}$ The Blues differ from other large insurers currently competing for managed care business because health insurance is the only product the Blues have generally been permitted by statute to sell. State legislatures have, however, usually granted them special financial privileges enabling them to price their fee-for-service and other insurance products attractively. ${ }^{93}$ They thus have intimate knowledge of the health insurance market and well-established, long-standing relationships with providers and employer-purchasers of group health insurance as well as with insured patients.

The Blues also have extensive administrative experience, extremely high visibility as a not-for-profit health insurer, prestige in many areas as a fiscal intermediary for such governmental programs as Medicare and its supplements, and generally excellent public relations. These factors promote a high degree of customer acceptance-if not brand loyalty-which tends to diminish defections to other insurers. ${ }^{94}$ In addition, Blue insureds are usually already involved in doctor-patient relationships with Blue-reimbursed physicians, which they are reluctant to disrupt by switching to non-Blue insurance programs in which their doctors may not participate.

All of these considerations give the Blues a competitive edge when they integrate vertically and attempt to enter the service delivery market through

92. In Massachusetts, for example, the Blues have commanded roughly $74 \%$ of the private health insurance market. Kartell v. Blue Shield of Mass., 749 F.2d 922, 924 (1st Cir. 1984). On the other hand, in California, Blue Cross and Blue Shield are separate and competing entities both of which insure hospital and physician services, and the Blue Cross market penetration is approximately 16\%. Barry v. Blue Cross of Cal., 805 F.2d 866, 874 (9th Cir. 1986). See also FTC Opinions and Order in In Re Michigan State Medical Society, 44 Antitrust \& Trade Reg. Rep. (BNA) No. 1103, at 426 (Feb. 24, 1983).

One commentator estimates that it takes the combined market share of 800 commercial insurers to equal the national Blue Cross market share. Greenberg, The Evolution of Blue Cross in a Competitive Marketplace, Bus. \& Health, Nov. 1986, at 44.

93. The Blues generally do business pursuant to state legislation for hospital service organizations granting them favored status with respect to state taxation, reserves requirements, and other issues. See, e.g., Mass. GEN. L. ch. $176 \mathrm{~A}, \S \S 1,19$ (1987). These statutes usually limit the business of the Blues to health insurance, however.

In several states the Blues have relinquished their tax-exempt privileges and converted to mutual insurance company status in order to compete as ordinary commercial insurers. See, e.g., ConN. GEN. Stat. AnN. § 19a-166 (West 1986).

For a detailed account of Blue Cross Association history, see S. Law, supra note 24.

94. Cf. Neipp \& Zeckhauser, Persistence in the Choice of Health Plans, in 6 Advances In Health Economics \& Health Services Research 47, 48-55 (R. Scheffler \& L. Rossiter eds. 1985) (presenting six reasons why people may ultimately switch plans). 
their own new PPO and HMO prepaid plans. ${ }^{95}$ Since they usually have no way to offset losses with increased business in other fields when their subscribers forsake them for different health insurers, stiff competition from prepaid plans presents a survival issue calling for an aggressive commercial response. That response seems to have been at least initially rather successful, even if somewhat belated; Blue prepaid plans now constitute the second-largest $\mathrm{HMO}$ network in the country, ${ }^{96}$ with more than 3.5 million subscribers in ninety HMO's nationwide. ${ }^{97}$

Aetna, CIGNA, Equitable, John Hancock, National, Metropolitan Life, Provident Life and Accident, Prudential, and Travelers are other large insurers actively involved in marketing prepaid health insurance products. These firms constitute nine of the ten largest insurance companies in the country, ${ }^{98}$ but they all have diversified product lines which permit them to absorb start-up losses in the health insurance market. Moreover, they can offer integrated group insurance packages to employers consisting of such components as life, disability, dental, travel accident, and accidental death and dismemberment coverage in addition to health insurance programs. Thus, they can often afford to forgo what would constitute customary profits on health insurance when sold as a single item in order to market a combined group insurance package to large employers, ${ }^{99}$ a tactic the Blues are usually prohibited by statute from emulating. These insurers ordinarily do not, however, have the degree of pre-existing fee-for-service health insurance market penetration possessed by the Blues.

Provider groups also aggressively market prepaid plans, but their share of the prepaid market has been declining as competition from insurance companies and other entities increases. ${ }^{100}$ The hospitals and physician groups sponsoring these prepaid plans already compete in the medical services market, however, and usually attempt to protect their competitive positions as providers by establishing defensive beachheads in the health

95. Vertical integration has been generally accepted as procompetitive by economic theorists, see 3 P. AREeda \& D. Turner, supra note 68, at $\uparrow 724$, at 195-96 (vertical integration in the absence of market power enhances market efficiency), although it was originally criticized as anticompetitive.

Vertical integration by a monopolist insurer, however, presents special considerations. Unlike the monopolist who produces and then sells the same product, the vertically integrated monopolistic insurer buys and then sells the same product-medical services. See Note, supra note 10, at 402-03. See also text accompanying Diagram 2. Cf. Kartell v. Blue Shield of Mass., Inc., 749 F.2d 922, 926-29 (Ist Cir. 1984), cert. denied, 471 U.S. 1029 (1985).

96. The largest is Kaiser-Permanente, supra note 31. See also Patricelli, Musings of a Blind ManReflections on the Health Care Industry, 5 Health Afrs., Summer 1986, at 128, 132 (chart of top eight HMO systems).

97. Press release, Blue Cross and Blue Shield Ass'n, Washington, D.C., Aug. 31, 1987. These raw numbers say little, however, about Blue prepaid plan strength in individual markets.

98. Patricelli, supra note 96, at 131 .

99. A recent commentator notes, " $[w]$ e estimate that a majority of group insurers have lost money in more years than not on medical insurance over the last decade. However, you would hope to do better on the other products in the package which usually produce higher margins." Id. at 132.

100. American Med. Care \& Rev. Ass'n, Directory and Survey of Preferred Provider Organizations and the Industry Report on PPO Development, Table 2, at x (1987), reported in 20 Internal Med. News No. 18, at 3, col. 2 (1987). 
insurance market. From an antitrust perspective their circumstances thus constitute in one sense the reverse of the Blues' situation. These providers are entering the insurance market to protect provider market position, rather than vice versa. Rarely, however, will a provider-sponsored prepaid plan have a medical services market critical mass that even approaches the usual Blue share of private health insurance business. ${ }^{101}$ Market power in their provider "home base" will thus ordinarily be lacking. ${ }^{102}$ Moreover, any negative impact on their competitive position as providers produced by the vertical restraints common to managed care plans will be self-imposed.

The law of antitrust relating to monopoly is fairly well-developed; what little monopsony analysis there is in the cases ${ }^{103}$ has generally tracked the law of monopoly without much attention to whether the anticompetitive impact of a dominant buyer's power to depress price in a subordinate market might differ significantly from the impact of a dominant seller's power to raise consumer prices unilaterally. ${ }^{104}$ In both monopolistic and monopsonistic situations, output will theoretically be below the competitive norm, thus producing allocative inefficiencies. ${ }^{105}$ The monopsonist's power to depress price operates initially to the detriment of sellers and the sellers' market itself rather than to the immediate disadvantage of consumers, however, as is the case when supra-competitive prices are obtained by monopolists. A seller with monopolistic attributes may also possess a secondary source of strength

101. Cf. Weller, Antitrust Aspects of PPO's, in Preferred Provider Organizations 189, 202-04 (D. Cowan ed. 1984) "[T]here are no established rules on the maximum combined market share of participating providers that the antitrust laws will allow." Id. at 204.

102. Cf. Arizona v. Maricopa County Medical Soc'y, 457 U.S. 332, 339, 354 n.29 (1982), wherein $70 \%$ of the physicians in Maricopa County were involved in a horizontal price-fixing cartel through a Foundation for Medical Care. The Foundation offered its members' services at fixed maximum prices to insurers, but did not sponsor its own prepaid plan.

103. Rovner, Monopsony Power in Health Care Markets: Must the Big Buyer Beware Hard Bargaining?, 18 Loy. U. CHI. L.J. 857, 862 n.24 (1987) ("[a] Lexis search for cases mentioning monopsony, monopsonist, monopsonize and related words located 40 opinions, eight of which do not involve Sherman Act claims. Of the 32 Sherman Act cases, nearly all make only a passing reference to monopsony. Only one-Custom Auto Body, Inc. v. Aetna Casualty \& Sur. Co., 1983-2 Trade Cas. (CCH) $\uparrow 65,629$, at 69,185 (D.R.I. 1983) . . . attempts to identify a set of elements to be proved to establish an abuse of monopsony power.").

104. See Vogel v. American Soc'y of Appraisers, 744 F.2d 598, 601 (7th Cir. 1984) ("Monopoly and monopsony are symmetrical distortions of competition from an economic standpoint."). Very little has been written about how the law should treat monopsony, as distinct from monopoly, however. See H. Hovencamp, Economics and Federal Antitrust Law $\$ 1.2$, at 17-18 (1985) ("[M]onopsony can impose social costs on society similar to those caused by monopoly." Id. at 17); G. Stigler, The Theory of Price 205-07 (3d ed. 1966) (economic analysis of differences between monopolists and monopsonists). See also Kallstrom, supra note 25, at 663 n.71. But see Rovner, supra note 104 (arguing for a rule of per se legality for monopsony).

Economists, especially those following the Chicago School, often view monopsony as a positive market factor, since monopsonistic buyers usually drive prices down. Note, supra note 10 , at 402 (citing H. Hovencamp, supra, at 150). But see Pauly, Monopsony Power in Health Insurance: Thinking Straight While Standing on Your Head, 6 J. HEALTh ECoN. 73, 73 (1987) ("monopsony may have seriously adverse consequences for overall economic efficiency, whatever it does to price and expenditure levels."); Note, Death Before Comparable Worth: The Limited Utility of Comparable Worth Evidence in a Title VII Cause of Action, 51 Mo. L. REv. 811,835 n.155 (1986) (empirical evidence supporting argument that monopsony power depresses labor wages is "virtually non-existent").

105. 3 P. Areeda \& D. Turner, supra note 68, at \964, at 201 . 
as a monopsonistic middleman buyer. The Blue fee-for-service role in many jurisdictions may generate such additional power, derived from Blue nearmonopoly status in its original insurance product market. When this is the case, the potential for a doubly adverse allocational effect exists. ${ }^{106}$ If that derivative monopsonistic power is exercised to exclude competitors at either level, both monopoly and monopsony will be even further entrenched.

Health insurers occupy a dual role as sellers of the managed care product and as buyers of the medical services that are managed to produce subscriber benefits. The vertical restraints/monopoly issue presented by litigation against the Blues concerns the impact of challenged Blue practices for managing care on the market for health insurance. It also involves the derivative disruptive effect of challenged behavior on competition in the market for health services. ${ }^{107}$ The vertical restraints/monopsony issue raised by these cases, on the other hand, targets the impact of Blue behavior as a dominant buyer on the medical services market itself. But monopsonistic activity can produce secondary effects in health insurance markets as well, which tend in turn to solidify Blue dominance. This double-edged monopoly/monopsony effect, occurring when powerful insurers impose vertical restraints affecting both provider and insurer markets, has been inadequately explored by the courts. When examined closely, certain of these vertical restraints common to managed care plans appear to have been used more to exclude competitors than to contain costs and thus enhance competition. ${ }^{108}$

Historically, monopsony conditions have been relatively uncommon in the general economy for a variety of reasons. ${ }^{109}$ Even when monopsony exists courts have generally refused to find Sherman Act violations.110 One

106. R. Just, D. Hueth \& A. Schmitz, Applied Welfare Economics and Public Policy 226 (1982) ("Note that [referring to diagram] the loss with both monopoly and monopsony power exercised is greater than if only one of these were exercised. In this context, two [simultaneous] distortions give rise to a greater welfare loss than one . ...").

107. Traditional monopoly analysis has never been a particularly comfortable fit for the health insurance model, however. Health insurance is a somewhat unusual consumer good, often subsidized by employers and at least nominally regulated by government. Health insurers have no incentive to restrict output in order to raise consumer prices, the traditional measure of market power, even though demand may be relatively inelastic. They usually have exhibited instead a "nonrational" preference for size and growth. Cf. infra text accompanying note 111 .

108. See infra text accompanying note 214 .

109. Buyers' cartels in professional sports provide a rare example of modern monopsony power. J. Hirshleifer, Price Theory and Applications 434 (2d ed. 1980). See Note, Monopsony in Manpower: Organized Baseball Meets the Antitrust Laws, 62 YALE L.J. 576 (1953).

Monopsony conditions also prevailed in the natural gas industry during the 1930's-1950's, when natural gas producers had little expectation or ability to bargain for price increases. Tannenbaum, Commercial Impracticability under the Uniform Commercial Code: Natural Gas Distributors' Vehicle for Excusing Long-Term Requirements Contracts?, 20 Hous. L. Rev. 771, 775-76 (1983) (citing Pierce, Natural Gas Regulation, Deregulation and Contracts, 68 VA. L. REv. 63, 79-80 (1982)).

110. See, e.g., Paschall v. Kansas City Star Co., 727 F.2d 692, 701-04 (8th Cir. 1984) (en banc), rev'g 695 F.2d 322 (8th Cir. 1982) (monopolist newspaper acquiring monopsony power in distribution of its papers benefitted readers by providing reduced prices and wider range of services); Kartell v. Blue Shield of Mass., 749 F.2d 922, 929 (1st Cir. 1984), cert. denied, 471 U.S. 1029 (1985) (courts will not interfere with assumed monopsonistic buyer's non-predatory determination of price).

A recent commentator asserts that "[n]o court has yet accepted monopsonization as a viable section 2 claim ...." Rovner, supra note 103, at 880 (emphasis added). Technically, the assertion 
explanation for the apparent dearth of monopsonistic behavior may have relatively little to do with economics. Many businesses that have the ability to depress input prices by restricting purchases because they are the only buyers of a particular product simply prefer size and growth to profit maximization. ${ }^{11}$ This apparently non-rational preference for expansion over pure profits inhibits the exercise of true monopsonistic power to extract a lower price.

Only rarely will a resource command a higher value in the hands of a purported monopsonist than elsewhere, where presumably it could command a higher return. ${ }^{112}$ Physician services, however, may be so highly specialized that they lack the flexibility required for efficient use in non-medical contexts. The supply curve for physicians may therefore look relatively inelastic, at least in the short run. ${ }^{13}$ Powerful health insurers may thus be able to depress physician prices below "competitive" levels ${ }^{14}$-without driving doctors out of the medical services market-because doctors can find few better-paying alternative uses for their skills. These insurers can continue to service their share of the health insurance market-or even grow-while extracting a price for the medical input to their product that is allegedly lower than a competitive market would ordinarily bring.

Monopsonistic insurer-buyers also may be able to depress hospital prices below competitive rates without forcing hospitals from the market for the same reason, but only in a much shorter time frame. Hospitals usually receive income closely tied to utilization of their facilities. Hospitals with occupancy problems-of which there are many in the United States ${ }^{115}$ - cannot operate at a loss for long once the obvious efficiencies forced by third party payer vertical restraints have been achieved, for few of them enjoy substantial endowments. More than half of hospital operating costs consist of labor expenses paid principally to non-physicians. ${ }^{116}$ Although a physician might be willing to forgo some income to remain in professional practice, nonphysician hospital personnel can ordinarily find alternative employment at competitive wages elsewhere in the economy. Hospitals unable to meet

may be true, but it assumes that courts never use the terms monopsony and monopoly interchangeably. Reazin and Ocean State, which found the defendants guilty of $\$ 2$ offenses at trial level, can both be seen as monopsony cases notwithstanding the fact that the term monopoly rather than monopsony was apparently used throughout.

111. 4 P. Areeda \& D. Turner, supra note 68, at I $964 \mathrm{~b}$, at 204.

112. R. Posner \& F. Easterbrook, supra note 68 , at 150.

113. But see Law \& Ensminger, supra note 48.

114. Judge Breyer's opinion in Kartell, 749 F.2d at 927, acknowledged the theoretical possibility of pricing below "competitive" levels in health care, but sidestepped the analytical thicket of determining when such a situation might exist.

115. See American Hosp. Ass'n, supra note 49.

116. Labor costs have always accounted for a large percentage of hospital spending. The payroll component of the community hospital budget was $62 \%$ in 1965 and $51 \%$ in 1977 . Wing \& Craige, Health Care Regulation: Dilemma of a Partially Developed Public Policy, 57 N.C.L. Rev. 1165 , 1179 (1979) (observing that while labor costs have always occupied the major expenditure line in hospital budgets, in recent years these costs have not increased as fast as other expenses) (citing AMERICAN Hosp. Ass'n, Hospital Statistics at x, xiii (1978)). 
competitive wage payrolls due to underutilization and strict management of care by insurers are thus soon forced to close. ${ }^{117}$

When large fee-for-service insurers integrate into provider markets by offering prepaid managed care programs of their own, ${ }^{18}$ antitrust courts should critically examine the competitive impact of the insurer's vertical restraints on the fee-for-service sector of the services market. They should also be attuned to the secondary impact of these restraints on the insurance market itself. The Blues have entered the prepaid (managed care) market with their own vertically integrated HMO's and PPO's as a survival strategy to preserve the only insurance role usually permitted them by statute. The longrange competitive impact of their managed care restrictions on fee-for-service providers that are not even partially integrated under the Blue prepaid umbrella-and on the health services and insurance markets in generaldeserves more intense antitrust scrutiny than courts have generally given it thus far.

The initial impact of these managed care constraints may enhance consumer welfare in terms of lower prices for health services ${ }^{119}$ and therefore for health insurance. Competitive conditions in both the health service business and the insurance industry may in fact decline over time, however, if certain allegedly procompetitive managed care restraints in fact eliminate competitors. In other words, future competitive conditions in both provider and insurer markets could be impaired by dominant insurer behavior that seems on the surface to advance at least short-term consumer interests. The long-range impact could drastically reduce patients' range of medical provider choice and ultimately lead to higher consumer prices.

Five important recent federal cases have dealt with monopolization/monopsonization and other antitrust issues in the context of Blue Cross/Blue Shield vertical restraints on hospital and physician services. ${ }^{120}$ Analysis of these five cases against the Blues reveals that

117. Ten percent of the nation's hospitals are expected to close by 1995 , according to The Future of Healthcare: Changes and Choices, Arthur Andersen \& Co. and American College of Healthcare Executives, reprinted in Mass. Health Care, Feb. 1988, at 4, col. 4. This result would ordinarily be considered desirable in terms of eliminating excess supply. The potential for an explosion in demand for hospital beds stemming from the rising incidence of AIDS in the American population, at least in the urban population, raises the possibility that in this situation economic analysis may not predict the most efficient long-term solution for the problem. After Years of Empty Beds, NYC Hospitals Suddenly Overflowing, Medical World News, Apr. 11, 1988, at 13 .

118. The Blues do this when they form their own HMO's and PPO's, and many other powerful insurers are currently attempting the same thing. See generally Patricelli, supra note 96, at 128. See also Gabel, Ermann, Rice \& de Lissovoy, The Emergence and Future of PPO's, $11 \mathrm{~J}$. Health Pol., Pol'v \& $\mathrm{L}$. $305,314-16$ (1986).

119. For an analysis concluding that pricing efficiencies are less important to consumer welfare in the long run than are innovation and production efficiencies because, unlike the latter, they do not increase real output, see Brodley, supra note 23, at 1020. See also United States v. Corn Prod. Ref. Co., 234 F. 964 (S.D.N.Y. 1916) (short-run consumer desire for "an immediate fall in prices" may run counter to long-run interests).

120. Earlier challenges to Blue-provider contract provisions tended to focus on pharmacy agreements. See Group Life \& Health Ins. Co. v. Royal Drug Co., 440 U.S. 205 (1979) (agreement between Blue Shield and participating pharmacies whereby Blue Shield reimbursed pharmacies for prescription drugs purchased by insured merely an arrangement for the purchase of goods and 
purportedly monopsonistic behavior by buyers of health services possessing near-monopoly status in their fee-for-service health insurer role calls for extremely sophisticated antitrust analysis. These concerns are exacerbated when the alleged monopsonist uses its buying power to bolster an attempt to compete in the subordinate seller's market as well. In all of these situations the business justification for vertical restraints imposed by powerful insurers to manage care must be subjected to critical scrutiny.

Standard monopoly analysis usually concentrates on the effects of a monopolist's behavior on the market in which it is the dominant seller. It does not, however, adequately address the situation presented when a monopsonist uses buying leverage to facilitate its own entry as a competitor into markets in which it is already the monopsonistic purchaser. The powerful Blues may not technically rise to the level of monopolists and/or monopsonists in any or all of the following cases. However, the fact patterns illustrate the potential for destruction of competition when managed care constraints are imposed primarily to exclude competitors or to enhance a dominant insurer's competitive position as an integrated insurer-provider, rather than to promote efficiency. Powerful fee-for-service insurers may implement these restraints in the name of cost containment. Their real goal, however, may be to eliminate rivals in both provider and insurance markets.

Kartell v. Blue Shield of Massachusetts ${ }^{121}$ and Barry $v$. Blue Cross of California ${ }^{122}$ concerned physician complaints about, inter alia, the Blues' allegedly anticompetitive behavior in negotiating the prices and other terms of fee-forservice physician contracts. ${ }^{123}$ Ball Memorial Hospital, Inc. v. Mutual Hospital Insurance, Inc. ${ }^{124}$ and Reazin v. Blue Cross and Blue Shield of Kansas, Inc. ${ }^{125}$ dealt

services, and not the business of insurance); Royal Drug Co. v. Group Life \& Health Ins. Co., 737 F.2d 1433 (5th Cir. 1984) (identical agreements to provide pharmaceutical services to insureds did not provide evidence of tacit conspiracy); Medical Arts Pharmacy of Stamford v. Blue Cross \& Blue Shield of Conn., 675 F.2d 502 (Blue Cross is purchaser of prescribed drugs from participating pharmacies); and Sausalito Pharmacy v. Blue Shield of Cal., 544 F. Supp. 230 (N.D. Cal. 1981) (insurer not guilty of unlawful vertical price-fixing by setting date of reimbursement for participating pharmacies), aff'd per curiam, 677 F.2d 47 (9th Cir. 1982), cert. denied, 459 U.S. 1016 (1982).

Those cases routinely dismissed monopsonization (although apparently never using that term) claims on the ground that the Blues were simply acting as buyers of pharmaceutical products for their insureds, using their market position to get the best price possible. The pharmacy cases are not discussed in this article because drug prescriptions involve a standardized product which happens to be distributed in pharmacies, rather than a differentiated service subject to insurer control. The Blues in these cases were not themselves attempting to compete in the market for pharmacy services or for pharmaceuticals. The situation differs fundamentally from that occurring when vertical restraints imposed as a consequence of powerful leverage in the insurance market drive highly individualized services from a provider market that the same insurer is contemporaneously attempting to penetrate.

121. 749 F.2d 922 (1st Cir. 1984), cert. denied, 471 U.S. 1029 (1985).

122. 805 F.2d 866 (9th Cir. 1986).

123. Brillhart v. Mutual Medical Ins., 768 F.2d 196 (7th Cir. 1985), also involved a physician challenge to Blue Shield participating provider agreements, but the opinion did not address the plaintiffs' § 2 claims. See also Pennsylvania Dental Ass'n v. Medical Serv. Ass'n, 745 F.2d 248 (3d Cir. 1984), cert. denied, 471 U.S. 1016 (1985); Ratino v. Medical Serv. Ass'n, 718 F.2d 1260 (4th Cir. 1983).

124. 784 F.2d 1325 (7th Cir. 1986), reh'g denied en banc, Apr. 7, 1986.

125. 663 F. Supp. 1360 (D. Kan. 1987). 
with antitrust complaints from fee-for-service hospitals, competing in that role with the Blues' own preferred provider plan. Ocean State Physicians Health Plan v. Blue Cross and Blue Shield of Rhode Island ${ }^{126}$ involved a complaint from a fledgling HMO and its participating physicians about, inter alia, the Rhode Island Blues' use of a most-favored-nation clause. These cases present a spectrum of progressively more troubling antitrust concerns involving the vertical restraints inevitably involved when powerful insurers attempt to manage health care. These managed care restraints acquire intensified antitrust significance when the insurer concurrently offers its own prepaid plan to compete with the same fee-for-service providers it has historically reimbursed on a cost-pass-through basis. Legitimate business justification for restraints adaptable to exclusionary ends should be clearly demonstrated in all of these cases.

The Blues won both antitrust challenges brought by the doctors at the federal appeals court level, although the medical plaintiffs had won Kartell at trial. The Blues also won Ball Memorial, one of the cases filed by the hospital industry, at both trial and appeals court levels. A $\$ 5,378,941$ federal district court verdict against Blue Cross and Blue Shield of Kansas in Reazin was recently upheld, however, when the Blues attempted to exclude a large Kansas teaching hospital from direct-payment provider status in an effort to bolster its own faltering HMO. ${ }^{127}$ An exhaustive and somewhat disjointed federal district court opinion overruling motions to set aside the verdict, for judgment notwithstanding the verdict and alternatively for a new trial, in Reazin is currently on appeal. ${ }^{128}$ In Ocean State another federal jury found the Rhode Island Blues guilty of monopolization, but the verdict was overturned in the ruling on a motion for judgment notwithstanding the verdict.

\section{A. Kartell}

In Kartell v. Blue Shield of Massachusetts, Inc., 129 a group of Massachusetts doctors challenged the defendant-insurer's contractual ban on balance-billing as an illegal restraint of trade. ${ }^{130}$ The contract provision required all physicians participating in traditional Blue fee-for-service plans to accept Blue Shield reimbursement ${ }^{131}$ as payment in full for services rendered to insureds, while non-participating physicians received no Blue Shield payment

126. 692 F. Supp. 52 (D.R.I. 1988).

127. 663 F. Supp. 1360 (D. Kan. 1987).

128. File No. 87-1823 (10th Cir.).

129. 749 F.2d 922 (Ist Cir. 1984), cert. denied, 471 U.S. 1029 (1985). For extensive commentaries on Kartell see Law \& Ensminger, supra note 48, at 61; Wayne, Comment on Kartell v. Blue Shield of Massachusetts, Inc.,: An Antitrust Analysis of Blue Shield's Reimbursement Schemes, 11 AM. J. L. \& MED. 465 (1986); Comment, Blue Shield's Ban on Balance Billing and the Sherman Act: Kartell v. Blue Shield of Massachusetts, Inc., 19 Suffolk U.L. Rev. 1001 (1985).

130. Massachusetts physicians have also unsuccessfully challenged the constitutionality of an analogous state statute, banning balance-billing of Medicare patients for amounts in excess of Medicare-determined "reasonable charges." Massachusetts Medical Soc'y v. Dukakis, 815 F.2d 790 (1st Cir. 1987), cert. denied, 108 S. Ct. 229 (1987).

131. Blue Shield reimbursement is calculated on the basis of "usual and customary" fees, which in practice constitute a ceiling on price. Kartell, 749 F.2d at 923. 
whatsoever. ${ }^{132}$ In effect, the ban functioned to set maximum fees for Blue Shield physician services in the state, but doctors remained free to treat other patients and charge them whatever the market-or other insurance schemeswould bear. ${ }^{133}$

Blue Shield participating physician status was open to all Massachusettslicensed doctors; 99 percent of them in fact contracted to participate, in large measure because the Blues controlled about 74 percent of the state's private health insurance market. ${ }^{134}$ Failure to participate meant virtual isolation from a crucial source of patients; since care rendered by non-participating physicians could not at that time be reimbursed, doctors had powerful economic incentives to accept Blue Shield's contract terms.

Blue Shield's 'private insurance market dominance in Kartell was uncontrovertible; the trial court specifically found that the insurer had market power ${ }^{135}$ and the Court of Appeals for the First Circuit was willing to assume for the sake of argument that its finding was correct. ${ }^{136}$ Yet the Court of Appeals had no trouble refuting the plaintiffs' section 2 claims, even accepting that Blue Shield might use its market power to "obtain 'lower than competitive' prices." 137 The opinion simply stated that the reasons leading the court to conclude that the ban on balance-billing was not an unreasonable restraint of trade "also lead us to agree .. . that the practice does not constitute monopolization or an attempt to monopolize."138 As the Supreme Court noted in United States $v$. Griffith, ${ }^{139}$ however, "those things which are condemned by $\S 2$ are in large measure merely the end products of conduct which violates $\S 1 \ldots$ But that is not always true." 140

132. Mass. Gen. Laws ANN. ch. 176B, $\$ 7$ (West 1987) (prohibiting Blues from reimbursing for non-participating physician care), was abrogated in 1988, 1988 Mass. Adv. Legis. SErv. ch. 23, $\$ 56$ (Law. Coop.) (allowing reimbursement for medical services provided by non-participating providers).

133. Massachusetts physicians are not, however, permitted to bill Medicare and Medicaid patients whatever they choose. By statute Massachusetts doctors must accept assignment of their Medicare patients' right of reimbursement as a condition of licensure, and are not permitted to bill them more than Medicare-allowed charges. 1988 MAss. Acts ch. 475. The constitutionality of the statute was upheld in Massachusetts Medical Soc'y v. Dukakis, 815 F.2d 790 (1st Cir. 1987), cert. denied, 108 S. Ct. 229 (1987).

Similarly, Massachusetts physicians must accept the state's Medicaid payment as payment in full for services rendered to Medicaid beneficiaries. Medicare and Medicaid Amendments of 1980, Pub. L. No. 96-499 $\S 902,94$ Stat. 2612.

134. Kartell, 749 F.2d at $924-27$

135. Kartell, 582 F. Supp. 734, 741 (D. Mass. 1984).

136. 749 F.2d at 927 .

137. Id.

138. Id. at 931. This excerpt exemplifies the widespread failure of antitrust opinions to distinguish between monopoly and monopsony conditions. See supra text accompanying notes 103 04 .

139. 334 U.S. 100 (1948).

140. Id. at 106 (emphasis added). Cf. Aspen Skiing Co. v. Aspen Highlands Skiing Corp., 472 U.S. 585, 608 n.38 (1985) ("[I]n considering the competitive effect of [a] . . refusal to deal or cooperate ... it is not irrelevant to note that similar conduct carried out by the concerted action of three independent rivals with a similar share of the market would constitute a per se violation of $\$ 1$ ...."). 
In essence, the First Circuit held that Blue Shield's ability to obtain "prices that reflected its market power" 141 did not rise to the level of an antitrust offense. The reasonableness of the prices it obtained was considered basically irrelevant, so long as the pricing was not predatory. ${ }^{142}$ The opinion simply characterized Blue Shield as itself the buyer of medical services for the account of its insureds, using its (assumed monopsony) position to get the best price possible. ${ }^{143}$ The court did not, however, come to grips with the monopsony issue in any meaningful way, and in fact never even used the term. ${ }^{144}$ It utterly failed to evaluate whether long-range competitive conditions in the medical services market might be impaired by Blue Shield's undisputed middleman power to depress price below competitive levels. ${ }^{145}$

By characterizing Blue Shield rather than the patient-or the employeras the buyer of physician services, the court neatly eliminated the resale price maintenance issue which would theoretically have required per se treatment. ${ }^{146}$ But as we have seen, the medical service purchasing decision is more fragmented than the simple principal-agent model used by the court. ${ }^{147}$ The opinion brushed aside the point that the ban on balance-billing virtually eliminated potentially serious price competition in a significant portion of the private physician services market. ${ }^{148}$ The fact that Blue Shield used its leverage to extract lower physician prices than would otherwise obtain in a competitive market "suggest[ed to the First Circuit] that courts . . should be cautious-reluctant to condemn too speedily-an arrangement that . . . appears to bring low price benefits to the consumer." 149

The First Circuit's failure to explore the effects of Blue Shield's pricing methodology on competition in the medical services market from a section 2 perspective more thoroughly was analytically unfortunate, but did not prevent the court from reaching the correct result. In order to find a section 2 violation, assuming Blue Shield did in fact have monopsony power in the health insurance market, the court would presumably have had to find an

141. 749 F.2d at 928 .

142. Predatory pricing, a $\S 2$ offense, requires proof that price is below incremental cost, or its equivalent. Barry Wright Corp. v. ITT Grinnell Corp., 724 F.2d 227, 236 (1st Cir. 1983). For an analysis concluding that maximum price-fixing should not be subject to per se condemnation, see Easterbrook, supra note 77 , at 886. Cf. Kallstrom, supra note 25, at 645, 678-84 (arguing that maximum price setting for health services be permitted by insurers, but not providers).

143. Cf. Group Life \& Health Ins. Co. v. Royal Drug Co., 440 U.S. 205, 214 (1979) (insurer's direct reimbursement of subscriber drug costs to participating pharmacies "merely [an] arrangement ... for the purchase of goods and services by Blue Shield").

144. Pauly, Competition in Health Insurance Markets, LAW \& Contemp. Probs., Spring 1988, at 237, 261-63.

145. The court noted the defendant's assertion that the record failed to prove the lower seller output usually accompanying monopsony, as well as plaintiffs' evidence that low prices discouraged introduction of new medical techniques, but simply assumed the existence of market power without exploring any impact on competition of their respective positions. Kartell, 749 F.2d at 927.

146. See supra note 84 .

147. See supra Diagram 2.

148. But see supra note 61.

149. Kartell, 749 F.2d at 931 . 
intent to exercise that power so as to destroy competition. ${ }^{150}$ The ban on balance-billing was originally imposed in the mid-1970's, however, when Blue Shield was experiencing problems with its reserves and before it had encountered significant competition from other prepaid plans in the state. Anticompetitive animus for instituting the ban was therefore lacking; obtaining lower prices for consumers was presumably the driving force. Moreover, the opinion noted in dicta that the Blues were sufficiently regulated in Massachusetts to suggest governmental interest in monitoring serious long-run market deficiencies created by depressing price. ${ }^{151}$

The restraints inherent in Blue Shield's ban on balance-billing reach directly into the vertically linked medical services market, where health insurers have not historically competed themselves. Nonetheless a monopsonist-insurer's power to extract price and other concessions from providers has a potent impact on that services market, particularly when the supply curve of physicians may be relatively inelastic. ${ }^{152}$ Antitrust courts should examine that impact very closely when a powerful fee-for-service health insurer acquires its own separate stake in that market as a competing (prepaid health plan) provider. Successful marketing of the prepaid plan reinforces the insurer's monopsony position with respect to all providers, and increases its stronghold in the insurance market.

Massachusetts Blue Shield currently owns or participates in a joint venture relationship with eight HMO's in the state, and is on the verge of marketing its own PPO. ${ }^{153}$ Physicians in Massachusetts Blue HMO's agree to accept payment as prepaid health plan providers according to specified salary or fee schedule arrangements, so the ban on balance-billing for traditional fee-forservice care does not affect them directly in their HMO role. The ban may, however, be a factor inducing HMO physicians to become Blue or other prepaid plan providers in the first place. ${ }^{154}$

The Massachusetts Blues could attempt to enhance the competitive position of their HMO's and their new PPO product through vertical restraints more exclusionary than the ban on balance-billing, however. They could conceivably attempt to use their insurance market leverage over the price of fee-for-service physician and hospital services to exclude competing

150. American Tobacco Co. v. United States, 328 U.S. 781, 809, 811, 814 (1946). Cf. Aspen Skiing Co. v. Aspen Highlands Skiing Corp., 472 U.S. 585 (1985) (absence of business justification for refusal to continue joint marketing agreement sufficient to constitute monopolization).

151. Kartell, 749 F.2d at 931 .

152. Although the Massachusetts Medical Society alleges that physicians are fleeing the state in response to an unfavorable political and economic climate for practicing medicine including, inter alia, the ban on balance-billing, the available data refute that claim. See Knox, Threat of Doctor Shortage Disputed, Boston Globe, Sept. 12, 1988, at 19, col. 1.

153. 1988 Mass. Adv. Legis. Serv. ch. $23, \S \S 54,58$ specifically permits the Blues to establish preferred provider arrangements within the state, and the Commissioner of Insurance approved the Blue PPO proposal on March 30, 1989.

154. If the ban seriously diminishes fee-for-service physician income, doctors are more likely to work as salaried HMO physicians or to accept lower reimbursement as prepaid plan providers in return for an increase patient flow. 
prepaid offerings through such devices as most-favored-nation clauses, ${ }^{155}$ and exclusive dealing requirements. In that case, section 2 considerations-and in particular monopsony-specific analysis of the effect of Blue behavior on provider markets in combination with an exploration of monopoly effects in the insurance market-should become central to any antitrust challenge. ${ }^{156}$

\section{B. Barry}

Barry v. Blue Cross of California ${ }^{157}$ examined the situation presented when California Blue Cross entered the medical services market directly with its own preferred provider plan, but maintained its competing fee-for-service insurance product. Other prepaid plans had been highly successful in the state and had contained the Blue Cross share of the health insurance market to a relatively small percentage by national standards. ${ }^{158}$ In Barry, two doctors challenged the physician payment provisions of the California Blue Cross Prudent Buyer (prepaid health care) Plan, in which all California-licensed physicians were eligible to participate if they so chose. Ninety percent of preferred providers' fees were covered by Prudent Buyer insurance, whereas only 60 to 70 percent of non-participating physicians' fees were paid. Moreover, participating doctors were required to refer Prudent Buyer insureds to other Prudent Buyer physicians as a general practice, and to notify patients when referral was to an "outsider," who would in most cases cost the patient money out-of-pocket. ${ }^{159}$

The trial court granted summary judgment for Blue Cross and the plaintiff-physicians appealed. The Court of Appeals for the Ninth Circuit declined to apply per se analysis to the defendant's conduct, ignoring the possibility that price-fixing issues might be present, and cited Continental T.V., Inc. v. GTE Sylvania Inc. ${ }^{160}$ to the effect that non-price vertical restraints "are to be judged under the rule of reason." 161 It then went on to employ the rule of reason "in the twinkling of an eye" 162 and affirm the judgment below.

The appellate court in Barry agreed with the plaintiffs that the Prudent Buyer plan put non-participating physicians at a competitive disadvantage by discouraging insureds from using their services. But it did not agree that this

155. As, for example, the Rhode Island Blues did when they attempted to trim reimbursement for participating physicians who had also contracted to provide services to a rival prepaid plan for cut rates. See infra text accompanying note 198.

156. Cf. Berkey Photo v. Eastman Kodak, 603 F.2d 263, 275 (2d Cir. 1979), cert. denied, 444 U.S. 1093 (1980); United States v. Griffith, 334 U.S. 100, 108 (1948).

157. 805 F.2d 866 (9th Cir. 1986).

158. The Blues have approximately $10 \%$ of the private health insurance market in California, where prepaid plans have flourished for decades. California had 107 of the 535 PPO's operating in the country on July 1, 1987. 20 Internal Med. News No. 18, 1987, at 3, col. 3. Five of the ten largest PPO's in the country are also in California. Gabel, Ermann, Rice \& de Lissovoy, supra note 118, at 305,315 .

159. Referrals to non-participating physicians were also possible if agreed to by the patient, but they were contemplated to be the exception rather than the rule. Barry, 805 F.2d at 872 .

160. 433 U.S. 36 (1977).

161. 805 F.2d at 871 .

162. Id. (citing NCAA v. Board of Regents, 468 U.S. 85, 109-10 n.39 (1984)). 
"distorted" the market for physician care. ${ }^{163}$ In fact, the court held that the notification requirement when referrals were to non-participating specialists actually improved competition by giving patients more information about price. Although informed patients might be reluctant to use nonparticipating specialist care because it would cost them more money out-ofpocket, such are the usual consequences of pricing differentials in competitive markets. The Prudent Buyer plan did not prevent insureds from utilizing non-participating physician services, said the court; rather it injected an element of price competition into a health services market hitherto not particularly susceptible to price variations. Since patients were free to use non-participating providers, albeit at greater cost, it followed that neither a tying arrangement nor a boycott of non-participating physicians existed.

The Ninth Circuit's analysis of the plaintiffs' section 2 claim was brief and uninformative concerning the effect of the Prudent Buyer plan on competition in the market for either health insurance or medical services. The result, however, was probably correct because the Blues have never had the kind of dominating presence in the California private health insurance market that they enjoy in much of the rest of the country and thus were unlikely to have monopsony control of the provider market. Ordinarily a sine qua non of either the monopolization or the monopsonization offense is market power, usually defined as the defendant's "power to control market prices or exclude competition." 164

Apparently little evidence of the defendant's strength in the insurance market was introduced in Barry, and there was no discussion of possible monopsonistic behavior facilitated by the alleged monopoly. The opinion spoke only in terms of the Blues' insurance market "share," without discussing whether market share should be an exclusive proxy for the market power usually required to establish the section 2 offense in the first place. The decision simply stated that a 16 percent market share, which the court calculated the defendant more or less possessed, "is far below what we would require for a monopoly."165 The court cited an earlier decision ${ }^{166}$ where "a thirty-five percent market share did not permit an inference of monopoly power" 167 to dispose of the section 2 claim summarily. ${ }^{168}$

163. Market "distortion" in this sense means an artificial and inefficient departure from competitive conditions.

164. United States v. Grinnell Corp., 384 U.S. 563, 571 (1966). For a Chicago School analysis of the market power issue, see Landes \& Posner, Market Power in Antitrust Cases, 94 Harv. L. Rev. 937 (1981).

165. 805 F.2d at 874

166. Forro Precision, Inc. v. IBM, 673 F.2d 1045, 1058 (9th Cir. 1982), cert. denied, 471 U.S. 1130 (1985).

167. Barry, 805 F.2d at 874.

168. Courts have in fact found monopoly power at a wide range of market share percentages, even substantially below 50\%. Yoder Bros. v. Cal-Fla Plant Corp., 537 F.2d 1347, 1367-68 n.19 (5th Cir. 1976), cert. denied, 429 U.S. 1094 (1977). Cf. United States v. Aluminum Co. of Am., 148 F.2d 


\section{Ball Memorial}

Market share need not necessarily correlate with market power in the health insurance context, however, as the Court of Appeals for the Seventh Circuit was quick to point out in Ball Memorial Hospital, Inc. v. Mutual Hospital Insurance, Inc. ${ }^{169}$ That case concerned, inter alia, a monopolization charge against the Indiana Blue Cross/Blue Shield organization, which commanded a private health insurance market share considerably in excess of the 27 percent of Indiana's total population that it admittedly insured ${ }^{170}$-a share at least nine times larger than that of its nearest competitor. More important for purposes of monopsony-specific analysis, however, "throughout Indiana about $50 \%$ of all hospitals' revenue come [sic] from payments made by the Blues." 171

Ball Memorial was initiated by eighty of Indiana's 115 acute care hospitals, challenging implementation of the Blues' own PPO plan. The Blues had invited fee-discounted bids from all hospitals in the state to become preferred providers under this new prepaid offering, and eventually accepted bids from sixty-one of them. They also continued to offer their traditional fee-forservice insurance coverage. Blue PPO subscribers were to receive full reimbursement for agreed charges when PPO hospitals were used, but only 75 percent of charges were to be covered when care was delivered in a nonparticipating facility. As in Barry, PPO insureds had compelling economic incentives to utilize preferred providers and shun those who lacked participator status. Unlike those in Barry, however, non-preferred hospitals in Ball Memorial had no option to shed their outsider status. Their economic situation was thus potentially much more precarious than that of the nonparticipating physicians in Barry, particularly in light of the far greater degree of Blue insurance market penetration. ${ }^{172}$

The Ball Memorial decision upholding denial of plaintiffs' preliminary injunction motion asserts virtually at the outset that, “'[j]ust how 'large' the Blues are turns out not to matter, so we do not pursue the question"'173_a rather cavalier initial statement for an opinion devoted in large part to

\footnotetext{
416, 424 (2d Cir. 1945) ("it is doubtful whether sixty or sixty-four per cent [of the market] would be enough" to constitute a monopoly).

Some commentators suggest that a specific market share held by buyers is less likely to produce anticompetitive results than the same share held by sellers, so long as the "product is produced at long-run constant costs .... With price the same over the relevant ranges of output, . . a monopsonist ... would purchase up to the point where the additional net revenue to be gained from purchasing an additional unit would fall below the supply price." 3 P. AREeDA \& D. TURner, supra note 68 , at $\uparrow 964 \mathrm{a}$, at 202.

169. 784 F.2d 1325, 1335 (7th Cir. 1986), reh'g denied en banc, Apr. 7, 1986. See also FTC v. Indiana Fed'n of Dentists, 476 U.S. 447, 461 (1986) ("market power . . . is but a 'surrogate for detrimental [anticompetitive] effects”") (citing 7 P. AREeda \& D. Turner supra note 68, at 9 1511, at 429).

170. 784 F.2d at 1330 .

171. Id.

172. "All hospitals saw a PPO plan as a threat to revenues-those who participated in the plan might collect less per service rendered, and those outside the plan might lose volume." Ball Memorial, 784 F.2d at 1331 .

173. Id. at 1331. See Note, Ball Memorial Hospital: Section 2 Sherman Act Analysis in the Alternative Health Care Delivery Market, 14 AM. J. LAw \& MED. 249 (1988).
} 
exploring section 2 issues. Market share did not really count in this case, according to both the trial and appellate courts, because entry barriers are so low in the health insurance industry as to be virtually non-existent; the appellate court opinion asserts that there are "no barriers to entry" 174 because only a license and capital are required before new competitors can enter the field.

Technically those may be the only requirements; as the opinion points out, more than 1000 health insurers are licensed to do business in Indiana, and more than 500 of them actually conduct operations there. ${ }^{175}$ But in reality the assertion that no entry barriers exist rings false, since not one of the Blues' competitors has more than 3 percent of the private-let alone the totalIndiana health insurance market. ${ }^{176}$ An impressive, albeit declining, Blue market share was regarded as simply a reflection of the Blues' "success in offering the package of price and service that customers prefer, not any [true] market power."'177

The Ball Memorial analysis of entry barriers in the health insurance field was highly simplistic. Impediments to entry are hardly confined to regulatory hurdles and capitalization alone, as the court at least claimed to understand. ${ }^{178}$ They relate to the larger issue of whether existing firms have power derived from any source to exclude meaningful competition and therefore control price, but the opinion failed to explore adequately the facts of the situation in Indiana. To begin with, the opinion declined to acknowledge that inertia and brand loyalty can be highly significant factors in health insurance purchasing decisions generally. ${ }^{179}$ Nor did the Seventh Circuit give any weight to the competitive impact of the Blues' favorable tax status, summarily dismissing it instead. ${ }^{180}$ Moreover, the court completely disregarded the impact of the Blues' long-standing direct relationships with providers and insureds on the ability of other health insurers to compete effectively with both Blue fee-for-service and prepaid offerings.

Most importantly, however, the court ignored the impact of the Blues' feefor-service insurance market leverage on their ability to extract "lower than competitive" prices from hospitals contracting with the Blue PPO. ${ }^{181}$ Bluepreferred hospitals are virtually assured of a significant patient flow stemming from the Blues' ability to market their own PPO, capitalizing on pre-existing

174. 784 F, 2d at 1335 (emphasis added).

175. Id. at 1332 .

176. Id. at 1331 .

177. Id. at 1332 .

178. Ease of entry was also related to potential competitors' ability to "convert other productive capacity to the product in question or import the product from out of the area" quickly. Id. at 1335 .

179. The trial court had concluded that health insurance consumers are extremely price sensitive (Ball Memorial, Finding 8, 603 F. Supp. 1077, 1080 (S.D. Ind. 1985)), but persuasive evidence to the contrary exists. See, e.g., Neipp, Joachim \& Zeckhauser, supra note 94, at 48-52.

180. 784 F.2d at 1335 ("[T]he Blues ... may have an edge because of the lower tax Indiana places on premiums . . . but this sort of advantage is not pertinent here.").

181. See Demsetz, Barriers to Entry, 72 AM. Econ. Rev. 47, 52-56 (1982) (examining specific ambiguities in entry barrier concept and emphasizing close connection to predatory pricing). 
relationships and name recognition derived from their large fee-for-service insurance market share. And no Indiana hospital would choose to risk being unable to service those of its usual patient population who elect Blue PPO coverage by voluntarily forgoing preferred-provider status.

Blue-preferred hospitals have little incentive to give similar "discounts below competitive price" to other insurers who have not demonstrated potential to enroll significant subscriber populations. New entrants in particular cannot realistically offer the promise of a substantial patient flow or threaten hospitals with a significant loss of traditional patient base if they fail to sign on. These Blue-preferred hospitals, which are transformed at least superficially into Blue providers when they acquire preferred status, possess inherent power to exclude new entrants from favorable pricing arrangements. Even without a most-favored-nation clause requiring it, they might easily find it beneficial to help stifle development of competitors to the Blues' prepaid plan. ${ }^{182}$

Judge Easterbrook was unable to think of a reason-other than market power, which he had already neatly concluded did not matter for purposes of section 2 analysis-why hospitals would "give the Blues a price break that injures rivals." 183 But his inability to come up with an alternative explanation stems from his own faulty reasoning; he made the mistake of equating market power for the purpose of evaluating whether an insurance monopoly existed with market strength as a precondition for the exercise of monopsony power at the provider level.

The two issues are not necessarily symmetrical. Indemnity insurers do not purchase fee-for-service provider services directly, while the Blues often do. The Blues may thus have direct purchasing clout in provider markets, not possessed by their insurance competitors, that may not accurately reflect their actual insurance market competitive position. In other words, it is possible for them to look quite like monopsonists as far as providers are concerned, but lack true monopoly power as sellers of health insurance.

The Blues probably do not technically constitute monopolists as far as the health insurance market in Indiana is concerned, notwithstanding the appeals court's somewhat summary resolution of the entry barrier and therefore the monopoly issue. But analysis of the alleged Blue role as monopsonist is a separate matter and should focus initially on the impact of Blue buying power on conditions in the hospital industry. The Ball Memorial opinion devoted almost no attention to the challenged restraint's effects on the hospital market, however. But preferred provider status was a critical issue for the plaintiff hospitals precisely because they dared not ignore the Blues' potential

182. Blue Cross and Blue Shield of Kansas explicitly capitalized on this power by extracting a most-favored-nation clause from preferred provider hospitals in Reazin. 663 F. Supp. at 1375-77. At least one admitted goal of Blue Cross and Blue Shield's most-favored-nation clause was to "forestall other insurance companies from receiving any better prices" from competing hospitals. Id. at 1376 . The Rhode Island Blues did the same thing to physicians in Ocean State. See infra text accompanying notes $198,199$.

183. Ball Memorial, 784 F.2d at 1340. 
ability to direct a substantial volume of PPO patients to favored hospitalsand away from non-preferred ones. Their legitimate fear that the Blue PPO would be highly successful derived from the Blues' demonstrated marketing skills honed during lengthy Blue dominance of the fee-for-service insurance market.

The Ball opinion asserted that "the Blues are not trying to get a monopoly in a second market," 184 but it failed to offer any rationale for its bald assertion. Such a result would hardly be surprising, however, if the plan were successfully marketed and at least half of Indiana's hospitals were designated Blue-preferred providers in accordance with the original plan. As the Court of Appeals for the Second Circuit noted in Berkey Photo, Inc. v. Eastman Kodak Co., 185 "a firm may not employ its market position as a lever to create-or attempt to create-a monopoly in another market," but the logical outcome of the Indiana Blue strategy tends precisely in that direction. ${ }^{186}$

The financial survival of many Indiana hospitals could be directly imperiled by inability to achieve Blue Cross preferred provider status, as substantial numbers of prospective patients will be deterred from using them. Blue Cross could thus conceivably function as the private arbiter of which Indiana hospitals survive financially-and which fail-by virtue of the way it awards preferred provider contracts. ${ }^{187}$ Moreover, Blue Cross will itself profit in both markets in which it competes if it helps to precipitate these hospital failures. ${ }^{188}$ Its dominance of the health insurance market will be enhanced by even stronger leverage to extract favorable rates from preferred providers not anxious to share the fate of their former competitors. ${ }^{189}$ Its competitive

\section{Id. at 1339 .}

185. 603 F.2d 263, 275 (2d Cir. 1979), cert. denied, 444 U.S. 1093 (1980). See also Telex Corp. v. IBM, 510 F.2d 894 (10th Cir. 1975) (extension of monopoly power from one market to another illegally restrains trade).

186. The Supreme Court observed by way of dicta in United States v. Griffith, 334 U.S. 100,108 (1948), that monopoly power cannot be used "to beget monopoly." Cf. SmithKline Corp. v. Eli Lilly \& Co., 575 F.2d 1056 (3d Cir. 1978), cert. denied, 439 U.S. 838 (1978) (unlawful to use monopoly power in product market to leverage sale of drug manufacturer's competitive product by linkage to sales of drugs on which manufacturer faced no competition).

187. As noted in Reazin v. Blue Cross \& Blue Shield of Kansas, 663 F. Supp. 1360, 1420-21 n. 16 (D. Kan. 1987) (citing Ball itself, 784 F.2d at 1342) (" '[o]ne frightening aspect of Ball Memorial ... is that in selecting providers for its PPO ... B [lue Cross of Indiana] unequivocally rejected one hospital's bid of a $20 \%$ discount from its normal charges. . " because " they concluded that it was not as conveniently located as Parkview Hospital in the same city." ").

188. From the standpoint of consumer welfare, business failure is often a healthy result of the competitive struggle; resources are diverted from unproductive uses into more efficient deployment in other sectors of the economy. Excess hospital beds abound in Indiana-forcing some hospitals to close because they are not efficient enough to grant the price discounts required by the Blues to achieve "preferred" provider status (theoretically that just reallocates those resources to more productive uses). From a pure antitrust perspective, this should be a favorable outcome.

The analysis is not all quite so simple in the hospital industry, however. Shifts in regulatory versus competitive attitudes on the part of government have caused some turmoil over the true level of need for hospital beds. In addition, the specter of a rapidly increasing population of seriously ill AIDS patients is beginning to raise substantial uncertainties about predictions of a declining longterm need for hospital capacity. See supra note 117.

189. See Feldman \& Greenberg, The Relation Between the Blue Cross Market Share and the Blue Cross "Discount" on Hospital Charges, 48 J. Risk \& INS. 235 (1981) (empirical evidence provides "some evidence" that Blue Cross's ability to discount increases market share). See also Pauly, supra note 144. 
position as a (prepaid plan) provider will also be strengthened because fewer hospital rivals will exist. ${ }^{190}$ Consumers will thus ultimately have fewer choices for either insurers or hospitals, although they may have short term lower prices.

\section{Reazin}

Reazin v. Blue Cross and Blue Shield of Kansas, Inc. ${ }^{191}$ took the managed care restraints of a powerful insurer, trying to compete also in the health services market via its own HMO and PPO, a significant step further with an exclusive dealing requirement. ${ }^{192}$ Reazin involved a Kansas teaching hospital's claim that the Blues' proposed termination of its provider status, on the sole ground that the hospital had contracted to provide services to a competing prepaid plan with which it had integrated vertically, violated the antitrust laws.

The convoluted facts involved in Reazin consume more than thirty pages of the Federal Supplement, ${ }^{193}$ but in simplistic fashion they are as follows. Blue Cross and Blue Shield of Kansas has traditionally dominated the state's private health insurance market, with a relevant market share approaching 60 percent-fifteen times larger than that of its nearest competitor. ${ }^{194}$ Moreover, Blue standard contracts had a most-favored-nation clause which required providers to offer the Blues the lowest rates they made available to other insurers. Realizing that their market share for traditional health insurance was nonetheless threatened by the emergence of certain prepaid plans, the Blues belatedly began to market their own HMO and PPO in addition to their established fee-for-service plan.

The Blues' stiffest competition was coming from a vertically integrated venture created by the largest proprietary hospital chain in the country, Hospital Corporation of America ("HCA"). HCA had acquired both Health Care Plus ("HCP"), the most successful HMO in the county surrounding Wichita, and Wesley Memorial Hospital. Wesley is the largest teaching hospital in the Wichita area and accounts for 10 percent of all hospital admissions in Kansas. HCA had also acquired an insurance company licensed to do business in the state. HCA was thus able to put together an extremely strong, attractive, prepaid care package for Wichita consumers, and the Blues were finding it hard to penetrate the market HCP had already captured with this prepaid plan. Moreover, Blue fee-for-service business was beginning to decline as prepaid care started to gain ground throughout the state.

190. As some hospitals close their doors for financial reasons, however, the bargaining leverage of those remaining could theoretically increase so long as multiple insurers remain in the market.

191. 663 F. Supp. 1360 (D. Kan. 1987).

192. A most-favored-nation clause was also involved in Reazin, but will not be discussed specifically herein. For a somewhat analogous most-favored-nation clause case concerning dentists rather than hospitals, see Kitsap Physicians Serv. v. Washington Dental Serv., 671 F. Supp. 1267 (W.D. Wash. 1987).

193. 663 F. Supp. at 1370-1401.

194. Id. at 1416 . 
After a complicated series of negotiations with all the Wichita hospitals concerning participation in Blue prepaid plans, the Blues notified Wesley that its participating provider status under the Blue fee-for-service plan would be terminated on January 1, 1986. Allegedly the decision to terminate was based squarely on Wesley's vertical integration as a provider in HCA's competing prepaid offering. Thereafter the Blues sent a memorandum to all Kansas hospitals stating:

[I]f hospitals decide to compete with Blue Cross and Blue Shield in the manner that HCA is competing, Blue Cross and Blue Shield must make a business decision about its future relationship with these entities. Hospitals that wish to continue their current relationship with Blue Cross and Blue Shield, that abide by the terms of our hospital agreement, that do not seek to enroll subscribers in other programs, and that wish to cooperate with Blue Cross and Blue Shield as a major marketing arm of the hospital, will experience no change in the contractual relationship that has historically served Kansas well. ${ }^{195}$

The message conveyed by this memorandum virtually requiring exclusive dealing was clear. Hospitals engaging in cooperative risk-sharing with other prepaid plans would be punished through deprivation of participating provider status under the Blue fee-for-service plan. Although Blue insureds would still be reimbursed for allowable expenses in these non-participating hospitals, excluded facilities would lose the benefit of guaranteed direct payment from the Blues for Blue subscriber care. In other words, loss of participator status would convert fee-for-service Blue coverage from direct payment to indemnity form. Although the rate of reimbursement would theoretically remain the same, hospitals would in effect be forced to assume the risk of patient non-payment. Moreover, non-participant hospitals would incur the costs and delays of having to administer direct patient billing and collection services themselves.

Based on these and other facts, a federal court jury found an illegal conspiracy among the Blues and certain Wichita hospitals in restraint of trade under section 1. In essence, it found the Blues guilty of conspiring with Wesley's competitors to terminate Wesley's provider status in order to stifle development of HCA's competing prepaid (managed care) offering. The jury also held the Blues guilty of violating section 2 . It specifically found that the Blues had the requisites of market power-the ability both to exclude competitors and to control price. ${ }^{196}$ The jury determined in addition that the Blue threat of retaliation against Wesley and other hospitals cooperating with competing prepaid plans was deliberately intended to thwart competition in the health insurance market.

\section{E. Ocean State}

Recent antitrust litigation against the Blues in Rhode Island has also explored the issue of exclusionary conduct. Ocean State Physicians Health Plan, a fledgling Rhode Island open-panel HMO, accused Blue Cross and

195. Plaintiff's exhibit 468-C, at 2, reprinted at $663 \mathrm{~F}$. Supp. 1388.

196. Reazin, 663 F. Supp. at 1399. 
Blue Shield of Rhode Island, which allegedly controlled 80 percent of the state's private health insurance market, of attempting to use leverage derived from monopoly-insurer status to force it out of business. ${ }^{197}$ The HMO charged, inter alia, that the Blues attempted to drive it from the market by financially punishing those Blue-participating physicians who had also contracted with Ocean State. The Blues allegedly accomplished this by implementing a most-favored-nation reimbursement policy called "prudent buyer." Blue Shield withheld 20 percent of its physician reimbursement-but only for those of its doctors who were also Ocean State providers, and only for so long as they remained with the competing plan-when in order to remain solvent Ocean State told its physicians that it would not return 20 percent of their charge as it had done in preceding years. The effect of the Blue policy on doctors contracting with both plans can be visualized as follows:

\section{Diagram 3}

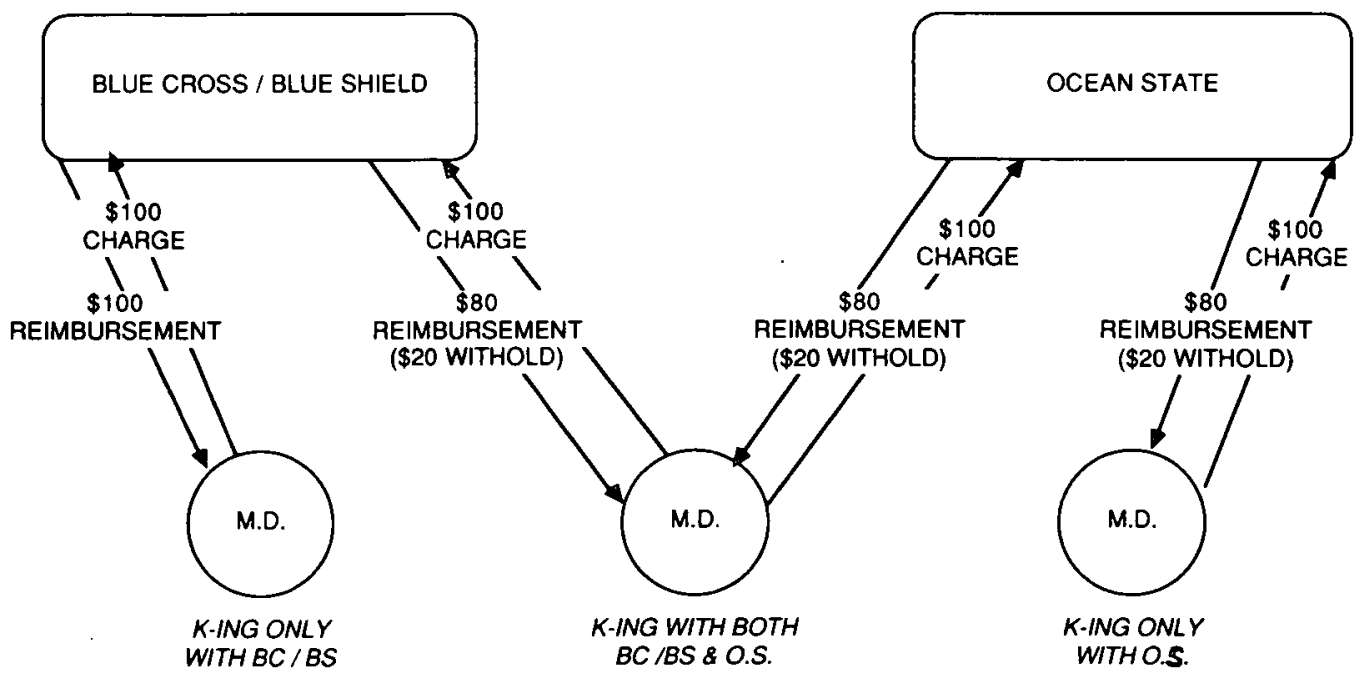

PHYSICIANS CONTRACTING WITH BOTH THE BLUES AND OCEAN STATE ARE PENALIZED THROUGH IMPLEMENTATION OF

The net result of implementing the prudent buyer policy was to decrease participating physician membership in Ocean State from 1200 to about 850 doctors. ${ }^{198}$ A federal court jury found the Blues guilty of monopolizing and attempting to monopolize Rhode Island health care financing-and of tortious interference with contractual relationship-through this and other

197. Ocean State Physicians Health Plan v. Blue Cross \& Blue Shield of R.I., 692 F. Supp. 52 (1).R.I. 1988).

198. Id. at 61 . 
maneuvers. ${ }^{199}$ The verdict was later overturned on a ruling for a motion for judgment notwithstanding the verdict, in large part because although the jury found the Blues guilty of a section 2 offense, it allocated the $\$ 3,193,437$ compensatory and punitive damages to the tort claims only. ${ }^{200}$

Most-favored-nation clauses are transplants from international trade agreements to the health insurance context. ${ }^{201}$ Traditionally they have been used to facilitate trade among signatory nations by creating a network of reciprocal trade benefits. ${ }^{202}$ Ironically, however, a powerful health insurer often imposes such a policy to erect trade barriers, rather than to eliminate them. ${ }^{203}$ The provision in effect bars competitors from negotiating special provider terms which might permit pricing of competing insurance products more attractively. ${ }^{204}$

Powerful insurers often use these clauses primarily to prevent new entrants from obtaining pricing advantages and thereby establishing market beachheads. They are not merely adapting to changes in the competitive climate by attempting to ensure non-discrimination. ${ }^{205}$ By requiring providers to grant them most-favored-nation protection as a condition of doing business, these powerful health insurers seek primarily the protection and enhancement of their existing market dominance rather than the simple prevention of price discrimination against themselves. The Justice Department has acknowledged the potential for anticompetitive abuse associated with these requirements in the health care context, but has stated that two factors must be present before it considers that anticompetitive impact occurs.

First, the third-party payer [imposing most-favored-nation treatment] must be so significant a factor in the [health insurance] market that a very high percentage of all providers feel they must contract with it. And, second, that payer must account for such a large portion of its providers' total billings that there is not sufficient provider capacity available to support entry into the market by other third-party payers [if the clause is enforced]. ${ }^{206}$

\section{Id. at 54 .}

200. Id. at $62-63,66$.

201. See 19 U.S.C. $\$ 1881$ (1982 \& Supp. IV 1986) (codifying this principle).

202. See, e.g., Legal Times of Washington, Jan. 21, 1980, at 12, col. 1 (most-favored-nations clause as fundamental principle of General Agreement on Tariffs and Trade ("GATT") accord).

203. Baker, supra note 65 , at 166 .

204. The Justice Department's Antitrust Division "is unlikely to challenge most-favored nation ... clauses ... that require the provider to charge the payer a fee no higher than the lowest fee ... [charged] any other patient ...." However, "[f]urther analysis is warranted when the third-party payer supplies at least $35 \%$ of the business of providers in the market," in which case the restraint will be scrutinized closely to insure that it was imposed not to deter entry but for legitimate business purposes. [Assistant Attorney General Charles F.] Rule says PPO's Physician Clauses Rarely Raise Competition Problems, 54 Antitrust \& Trade Reg. Rpt. 450 (Mar. 17, 1988).

205. If a provider were to discriminate against a particular insurer, a most-favored-nation clause would serve a legitimate procompetitive purpose in protecting it. But where an inefficient insurer would be eliminated from the market but for the protection afforded by the clause, or where it is employed primarily to exclude competitors, its effects are anticompetitive.

206. Remarks of Charles F. Rule, Assistant Attorney General, Antitrust Division, at the "Antitrust and Health Care" seminar of the antitrust section of the Connecticut Bar Association and the Connecticut Health Lawyers Association, Mar. 11, 1988. 
The first of those factors was certainly present in the Ocean State situation. Blue Cross and Blue Shield of Rhode Island covered more than 540,000 people, while Ocean State, the only other insurer of note, had enrolled only about 70,000 subscribers. ${ }^{207}$ Physicians failing to contract as Blue providers thus risked cutting themselves off from the lion's share of the privately insured patients in the state. Moreover, the Blues' claimed business justification for enforcing the prudent-buyer policy-saving money for subscribers-rang hollow. The Blues failed to adjust subscriber premiums to reflect the estimated savings from implementing most-favored-nation "penalties" and they applied those penalties only to Blue physicians also doing business with Ocean State, rather than across the board to all participating Blue doctors. If, as the court states, "Blue Cross is entitled to use its [uncontested] market power to get the best price for the services it purchases," 208 why did it not seek that "best price" from all of its participating physicians?

The second factor referred to by the Justice Department was probably also present in Ocean State, although precise data on the point are lacking. Presumably, more than one-quarter of Ocean State's participating physicians felt that their income from the Blues so far outstripped what they could receive from Ocean State that they preferred to forgo Ocean State provider status altogether rather than take a 20 percent withhold from the Blues. Under all of these circumstances, and accepting as true evidence that the Blues had discussed "conspiring with ... [another prepaid plan in the state] to 'shoot this outfit down'.. . [including] discrediting Ocean State's application . . . for a Certificate of Need,"209 the jury's verdict that the Blues intentionally engaged in anticompetitive conduct designed to maintain their undisputed market power seems correct.

\section{ConcLusion}

With leverage derived from strength in the fee-for-service insurance market, powerful health insurers may attempt to use vertical restraints to capture scarce or essential medical resources and deny them to competing prepaid plans. The most likely mechanisms for solidifying existing dominance are exclusive dealing requirements and most-favored-nation clauses, although other vertical restraints could lend themselves to predatory purposes as well. A vertical arrangement whereby a powerful insurer wields buying power with intent to keep essential provider resources in its own hands and away from prepaid plan challengers could well constitute

207. Ocean State, 692 F. Supp. at 57.

208. Id. at 71 .

209. Plaintiff's memorandum at 52 (citing defendant's document BC 18/67; Leco deposition at 13-16; unproduced document: Memorandum from J. Grant to A. Leco, Oct. 7, 1980). 
monopolization or monopsonization-or their attempts-under section 2 of the Sherman Act. 210

Exclusive dealing contracts often function procompetitively in the health care context; in many situations they can promote efficiency by, for example, reducing transactions costs. ${ }^{211}$ Exclusive dealing arrangements also, however, can be used to corner and hoard critical resources away from competitors with no more than a pretense of promoting efficiency-as was the case in Reazin. ${ }^{212}$ Thus, when powerful insurers insist on exclusive arrangements in their dealings with providers, reviewing courts should subject the requirement's business justification to close, critical examination.

A most-favored-nation clause alone in a Blue contract with providers might be upheld on the same theory that the First Circuit espoused in deciding Kartell-just another example of a powerful buyer getting the best price possible for an input to the final product rather than per se illegal resale price maintenance, or any other antitrust violation. However, imposing such a condition also could rise to the level of a section 2 violation. This might be the case if the insurer had such a high volume of subscribers that the provider could not afford pricing discounts for any other insurers, regardless of the incentive offered, because it could not afford to match them for the dominant insurer as required by the provision. In that event the insurer would be employing the requirement as a weapon to thwart entry by new competitors, rather than simply insuring for itself the same financial treatment afforded rivals.

In the long run, managed care vertical restraints imposed by dominant insurers and designed primarily to exclude prepaid plan competitors-rather than to produce more efficient service-could injure competition in both health services and health insurance markets. ${ }^{213}$ To the extent that such constraints successfully retard development of competing plans, providers will have little choice but to sell their services through these powerful local insurers. And since the insurer is the first-stage buyer in the three-step purchase of health services which consecutively narrows ultimate patient choice, ${ }^{214}$ that first purchase is a critical determinant of provider financial survival.

Powerful health insurers who have successfully excluded challengers could eventually decide to contract with a far smaller stable of providers than they have traditionally used, at even lower input prices, in order to capture monopoly and monopsony rents. Rather than pass the savings on to

210. Cf. SmithKline Corp. v. Eli Lilly \& Co., 575 F.2d 1056 (3d Cir. 1978), cert. denied, 439 U.S. 838 (1978).

211. See, e.g., Jefferson Parish Hosp. Dist. No. 2 v. Hyde, 466 U.S. 2 (1984).

212. Cf. United States v. United Show Machinery, 110 F. Supp. 295 (D. Mass. 1953), aff'd, 347 U.S. 521 (1954)

213. Aspen Skiing Co. v. Aspen Highlands Skiing Corp., 472 U.S. 585, 604 (1985) ("If a firm has been 'attempting to exclude rivals on some basis other than efficiency,' it is fair to characterize its behavior as predatory.").

214. See Diagram 2. 
insurance purchasers they could use them for purposes unrelated to patient welfare unless carefully regulated. If these insurers stave off competition from prepaid plan challenges to their dominance through these measures, excluded providers will have no market for their services. This economic pressure to contract excess supply may be an efficient result but the long-run situation is hardly the rosy picture for patient-consumers presented by cases like Kartel, Barry, and Ball Memorial. Eventually patient-consumers could find themselves paying more money, but being far less able to take their choice. 